\title{
Field reconnaissance and structural assessment of the October 30, 2020, Samos, Aegean Sea earthquake: an example of severe damage due to the basin effect
}

\author{
Onur Onat ${ }^{1}$ - Burak Yön ${ }^{2} \cdot$ Mehmet Emin Öncü ${ }^{3} \cdot$ Sadık Varolgüneş ${ }^{4}$. \\ Abdulhalim Karaşin $^{3} \cdot$ Selim Cemalgil ${ }^{2}$
}

Received: 14 July 2021 / Accepted: 9 December 2021 / Published online: 22 January 2022

(c) The Author(s), under exclusive licence to Springer Nature B.V. 2021

\begin{abstract}
An earthquake with a magnitude ranging from $\mathrm{Mw}=6.9$ (KOERI) to $\mathrm{Mw}=7.0$ (USGS) struck Samos Island in the Aegean Sea on October 30, 2020, with an epicentre $70 \mathrm{kms}$ from the İzmir city centre in Turkey. The earthquake took place at 14:51 local time (11:51 UTC). The peak ground acceleration (PGA) of this earthquake was recorded to be $0.179 \mathrm{~g}$ at the epicentre of the earthquake. This earthquake occurred at a depth of $17.26 \mathrm{~km}$ (AFAD (2020) İzmir Earthquake Report, (In Turkish)) and lasted $16 \mathrm{~s}$. The main shock from the earthquake triggered a tsunami that hit the building stocks built near the coast. During the gradual deregulation of COVID-19 pandemic regulations, various events caused considerable damage to the building stock, particularly in the Izmir Seferihisar and Bayraklı regions and resulted in a massive disruption of daily habits. The main shock caused 117 deaths in both Turkey and Greece, and 1632 people were also injured in Turkey. Moreover, several injuries occurred in Greece. A total of 103 buildings collapsed, 700 were severely damaged, 814 buildings were moderately damaged, and 7889 were slightly damaged. The basic aim of this paper is to briefly present the past and present seismotectonic characteristics of the region, present building stock, and former structural conditions before the earthquake, assess structural performance and classify distinguished earthquake-induced failures and damage due to the basin effect.
\end{abstract}

Keywords 2020 Samos earthquake $\cdot$ İzmir $\cdot$ Seismotectonic characteristics $\cdot$ Structural failure $\cdot$ Reinforced concrete structures $\cdot$ Masonry dwellings $\cdot$ Tsunami $\cdot$ Basin effect

Onur Onat

onur.onat@inonu.edu.tr

1 Civil Engineering Department, Inönü University, 44280 Malatya, Turkey

2 Civil Engineering Department, Munzur University, 62000 Tunceli, Turkey

3 Civil Engineering Department, Dicle University, 21280 Diyarbakır, Turkey

4 Civil Engineering Department, Bingöl University, 12000 Bingöl, Turkey 


\section{Introduction}

\subsection{Seismological aspects}

Earthquakes are a sparse and less frequent cyclic natural phenomenon with a substantial detrimental impact on living environments (Stepniac et al. 2021). Currently, Turkey, which is in the East Mediterranean, is one of the most active seismic zones in the world. This high seismicity results in numerous earthquakes (Calayır et al. 2012; Sayın et al. 2013; Sayın et al. 2014; Yön et al. 2019; Yön et al. 2020; Doğangün et al. 2021; Günaydın et al. 2021; Demir et al., 2020; Sayın et al. 2021; Doğan et al. 2021; Yön 2021) even in the previous year, 2020. This seismicity is caused by 326 separate faults, fault zones or combined systems. The longest traced fault zones were individually divided into sections based on their productivity of earthquakes. Finally, 485 separate fault sections considered as having the potential to produce seismic ground motion were identified across Turkey, as presented in Fig. 1.

As shown in Fig. 1, most of Turkey is vulnerable to earthquakes. This high seismicity is triggered by four different neotectonics districts (Fig. 2) that were discussed in (Yön et al. 2020) across Turkey. These include the (1) North Anatolian district, (2) Eastern Anatolian contractional district, (3) Central Anatolian planar district, and (4) Western Anatolian extensional district. Every district has particular tectonic characteristics. Based on the active fault presented in Fig. 1, the potential ground motion activity map includes a 475-year return period to demonstrate earthquake prone territory at this earthquake level, which is demonstrated in Fig. 2.

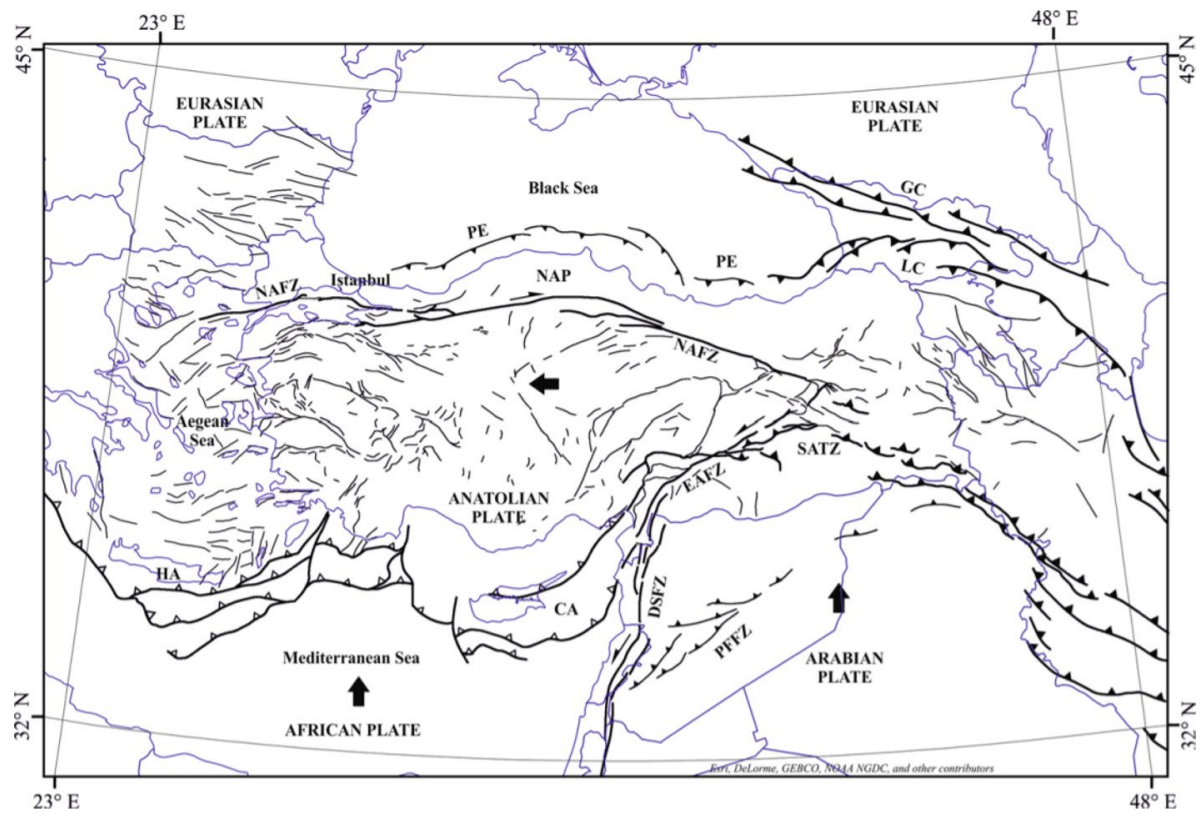

Fig. 1 Active tectonic features of Turkey (Sesetyan 2018) 


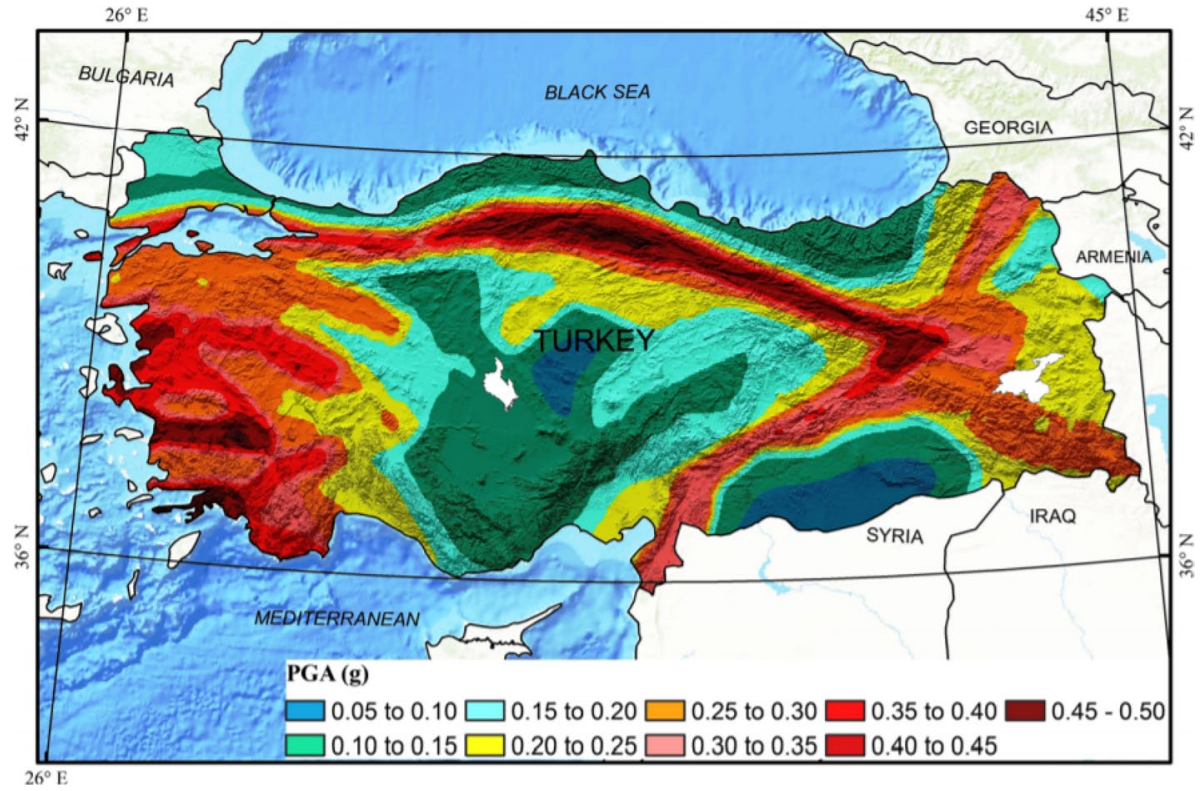

Fig. 2 Spread seismicity along Turkey territory in PGA according to 475 years return period (Sesetyan 2018)

These active tectonic features have caused numerous earthquakes in recent decades, particularly between 2003 and 2020. The earthquakes that occurred in the eastern part of Turkey were due to the East Anatolian Fault (EAF). In addition, the western part of Turkey is also under high seismic risk due to the subduction zone of the East Mediterranean. The Hellenic Arc is the most seismologically and geodynamically active domain in the Alpine Himalayan Belt. In the addressed ten year duration (2008-2017), nineteen earthquakes with $M \geq 6$ occurred whose epicentres were mainly located in southern Greece and western Anatolia and bound the Aegean plate, as presented in Fig. 3.

The cascade of severe earthquakes between 2008 and 2017 began with the 2008 Leonidio earthquake, which was an intermediate depth $(80 \mathrm{~km})$ earthquake under the eastern Peloponnese and broke a section of the African lithosphere. Durand et al. (2014) viewed the 2008 series of severe events and the subsequent rise in microseismicity in the Aegean basins as an extension of a gradual deformation episode started by the rupture along the descending plain. In this context, the updated list of seismic ground motion, which includes the 2017 sequences in the Lesvos Basin (Mw 6.3) and Marmaris-Kos ( $\mathrm{Mw}=6.6$ ), can be regarded as being events triggered by the slow spread of strain across western Anatolia, which continues to have the capacity to accumulate earthquakes in location and time (Kiratzi 2018). In the year 2005, Seferihisar was struck by an earthquake with a magnitude of $5.9(\mathrm{Mw})$. This earthquake verified that the seismic sequence would continue due to the velocity of the Hellenic Arc, which is between $25 \mathrm{~mm} /$ year and $28 \mathrm{~mm} /$ year (Doğru et al. 2014). In 2014, an earthquake with a magnitude of 6.5 (Mw) struck Gökçeada. After this earthquake, the performance of masonry dwellings was highly affected by this earthquake and was evaluated by Göçer (2020a, b). These earthquakes caused numerous deaths and damaged hundreds of buildings. Many seismic events occurred in Çanakkale during the first quarter of 2017. Structural assessments of traditional stone masonry dwellings after 


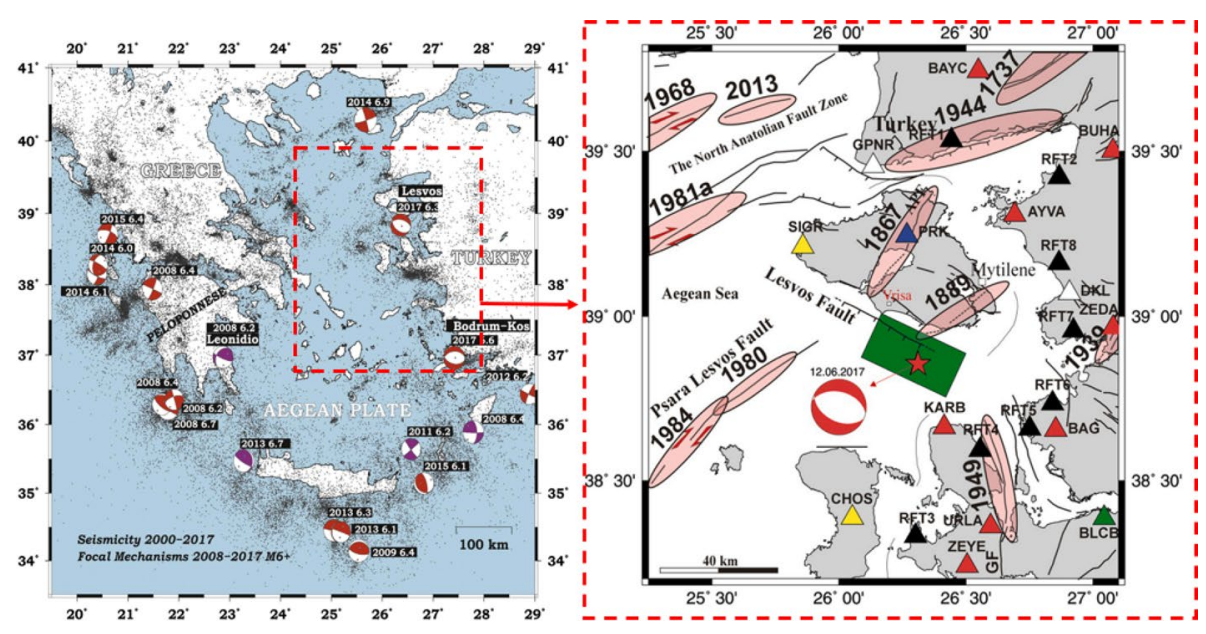

Fig. 3 Seismicity and focal mechanism of Aegean Plate (Adopted from (Kiratzi 2018; Utkucu et al. 2021), Red beach balls for $\mathrm{h} \leq 45 \mathrm{~km}$; magenta for $\mathrm{h}>45 \mathrm{~km}$ )

these seismic sequences were conducted by Aras and Duzci (2018). Seismic activity continued in 2017 with the Lesvos earthquake on June $12(\mathrm{Mw}=6.3)$. This earthquake had an impact on Karaburun Izmir in the region. Only stone masonry buildings were affected in rural areas. The performance of rural buildings was investigated by Vlachakis et al. (2020) and Göçer (2020a, b). Following this earthquake, the Aegean Sea region in Turkey was shaken for two months, particularly in 2020, before October 30. These seismic activities were the precursor to the main shock. On October 30, 2020, a strong $(\mathrm{Mw}=6.9)$ and shallow $(14.9 \mathrm{~km})$ earthquake struck Samos for $16 \mathrm{~s}$. The results of a site investigation and tsunami effects were discussed by Altunış1k et al. (2021). In the month following the main shock, 5068 aftershocks occurred, resulting in 117 deaths and 1632 injuries. This earthquake triggered a tsunami that killed only one person died. This person was the first to die because of a tsunami in Turkey.

\subsection{Tsunami aspects}

In the scientific community, the phrase "tsunami" refers to a series of waves with extraordinarily long wavelengths. Underwater earthquakes caused an abrupt vertical displacement of the seafloor, underwater sediment slides, and an above-sea level landslide that quickly fell into the sea. Volcanic activity beneath the seafloor all contributed to the tsunami. However, when these natural events are considered, underwater earthquakes are the primary cause of tsunamis (Heidarzadeh 2009). Tsunamis are categorized into three groups based on their location relative to the source. These include local $(<100 \mathrm{~km})$, regional $(100-750 \mathrm{~km})$, and distant $(>750 \mathrm{~km})$ tsunamis (Fernandez, 2000). Based on this basic introduction related to tsunamis, the global tsunami risk is demonstrated in Fig. 4.

The first recorded tsunami event occurred off the coast of Syria in B.C. 2000, as presented by (Gusiakov 2009). The second known destructive case of a tsunami occurred in the Aegean Sea and was generated by the catastrophic eruption of the Santorino volcano on Thera Island and was dated back to 1628 B.C. For the whole B.C. period, 23 historical events are known to have occurred. Most of them were concentrated along the densely 


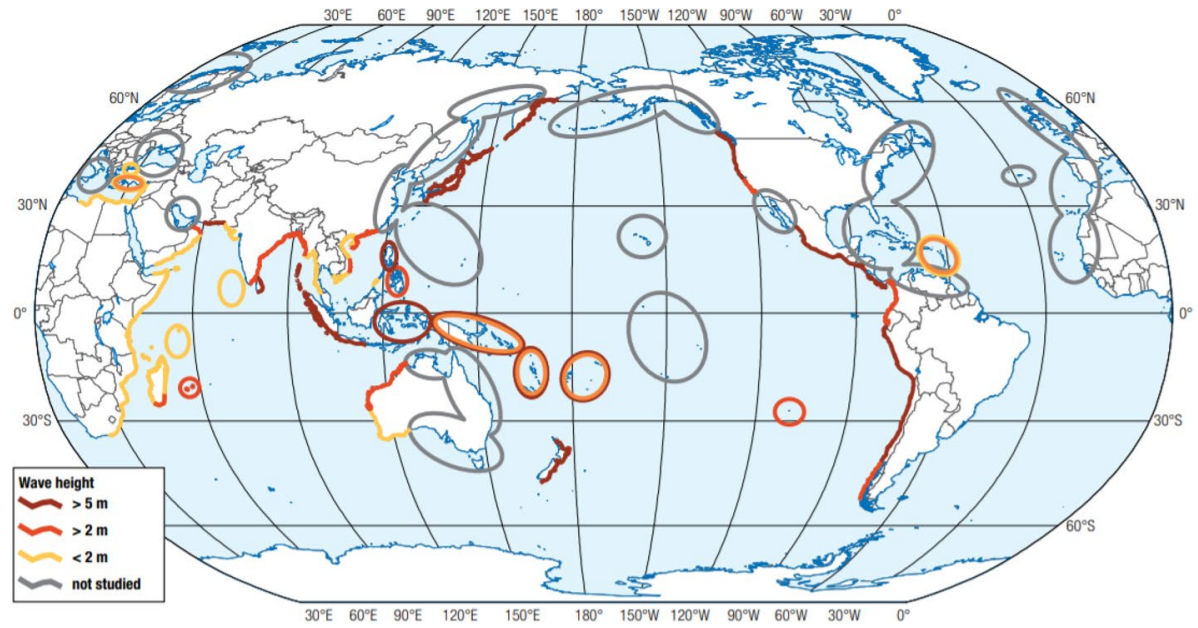

Fig. 4 Tsunami threat on a global scale [Adopted from (URL1)]

populated coastline of the Mediterranean (Gusiakov 2009). There were 49 historical earthquakes and tsunamis in Central America between 1539 and 1996 (Fernandez et al. 2000). The most catastrophic tsunami that took place on December 26, 2004, occurred after the Sumatra earthquake. More than 230.000 people died because of this tsunami due to the high seismic region of Markan in the Indian Ocean (Heidarzadeh et al. 2009). Historical tsunamis and the potential of a tsunami along the coastline of the Indian ocean are depicted in Fig. 5.

The effect of tsunami damage to structural systems was investigated by (Ammon et al. 2005; Lay et al. 2005; Lovholt et al. 2006). The March 11, 2011, Tohoku earthquake killed 16,000 people because of a tsunami-related earthquake (Mimura et al. 2011; Krausman and Cruz 2013). A total of 1347 people died due to the tsunami triggered by

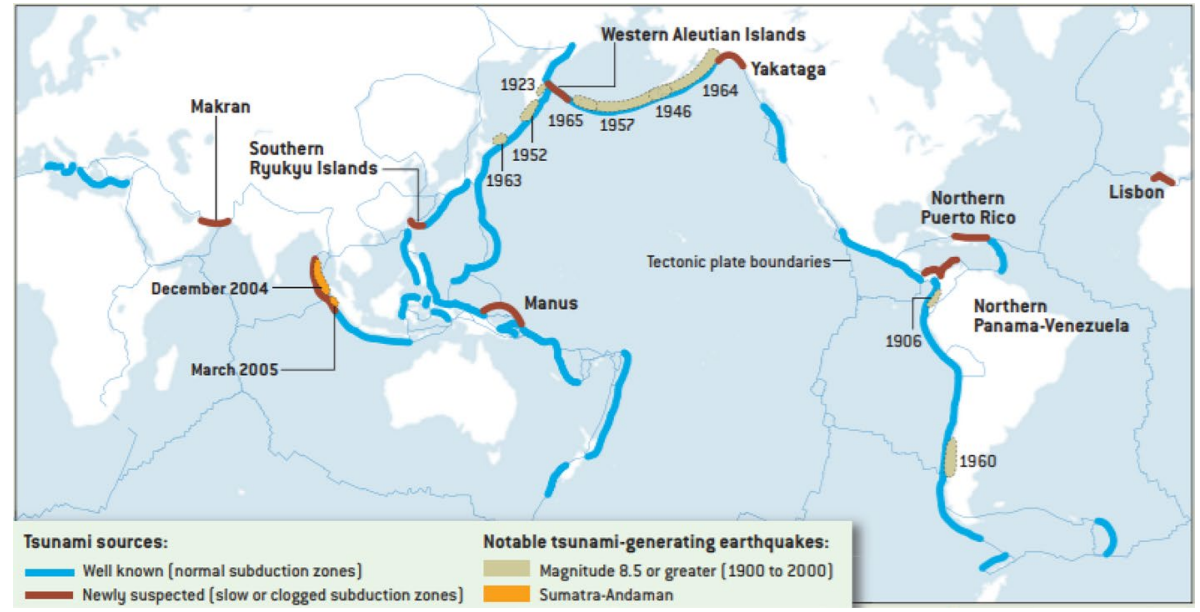

Fig. 5 Past and present earthquake and tsunami potential of coast of Indian Ocean [Adopted from (Geist et al. 2006)] 
the September 28, 2018, Sulawesi earthquake (Widiyanto et al. 2019). Damaged buildings were investigated by Widiyanto et al. due to effects from a combined earthquake and tsunami (Handayani and Puspasari 2020). Tsunami data show that the Pacific region is home to approximately $90 \%$ of large tsunamis (Liu et al. 2007).

This study aims to investigate and summarize past and present seismic characteristics of the Aegean Sea region. Another goal of the paper is to summarize the seismotectonic characteristics in this region, the general characteristics of earthquakes, an overview of building stock İzmir province. Specifically, to goal is to report on the structural damage and structural damage caused by the earthquake and tsunami observed during the site investigation. The damage was classified for reinforced concrete structures and masonry dwellings. The various types of earthquake-induced failures and damage were discussed. Moreover, lessons learned are presented in this study. In addition, the tsunami effect was also evaluated in terms of elevated maximum level, damage and other effects.

\section{Historical seismicity and tsunami in the mezzo scale}

\subsection{Seismicity}

İzmir is in western Turkey, at the western end of the Anatolian mainland. In the historical period from BC 1800-AD 1900 (KOERI 2020), earthquakes with varying intensity values occurred in the Great Menderes and Gediz Graben System in İzmir province and its vicinity, as seen in Fig. 6.

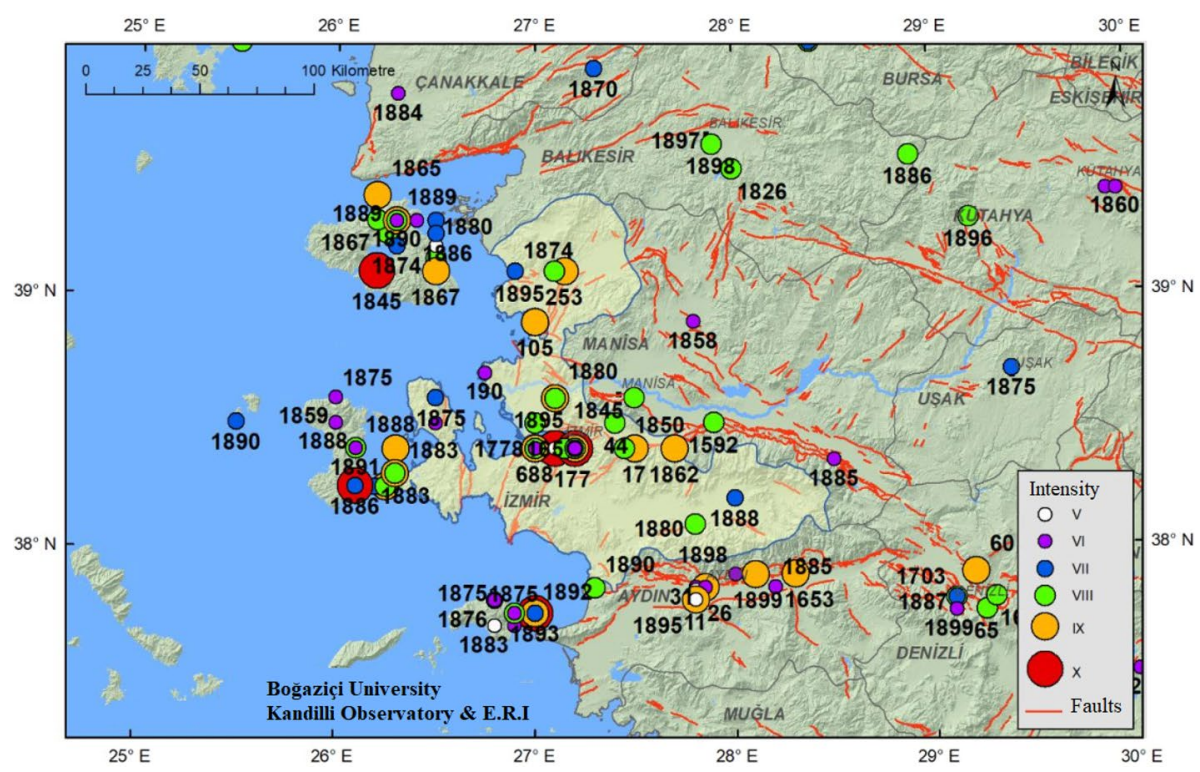

Fig. 6 Historical records around İzmir (KOERI 2020) 
A total of 332 earthquakes occurred in the region before 1900. In addition, 695 earthquakes were measured with a magnitude that was higher than 4.0, and the largest of them was 6.8. Instrumental period earthquakes can be seen in Fig. 7.

İzmir and the vicinity of the province experienced numerous earthquakes. The magnitudes of major earthquakes during the instrumental period around İzmir are plotted in Fig. 8.

\subsection{Tsunamis}

The most active part of the Aegean Sea in terms of seismicity is Izmir Bay, the Karaburun Peninsula and Chios Island. Between 496 BC and 1949 AD, 20 medium-scale earthquakes occurred and caused tsunamis in 1389, 1856, 1866, 1881, and 1949. The Amorgos earthquake in 1956 triggered a large tsunami that resulted in a $2.5 \mathrm{~m}$ high wave and $1.5 \mathrm{~km}$ deep flood area in Kilimli (Kalymnos) island. Severe material damage was observed in the Ünye (Ios), İncirli (Nisyros), Batnaz (Patnos), Papazlık (Tilos), and Lipsi (Lipsos) islands. The tsunami reached $1 \mathrm{~m}$ in Fethiye, and the flood depth was $250 \mathrm{~m}$ (KOERI 2020). Historical tsunamis and locations are shown in Fig. 9.

A severe earthquake with an instrumental magnitude of $6.6(\mathrm{Mw})$ and a depth of about $6 \mathrm{~km}$ occurred in the entire Southwest Aegean on July 21, 2017, at 01:31 local time in the Gulf of Gökova in the Mediterranean. This earthquake triggered a tsunami, and tsunami waves moved through Muğla province and the vicinity. This tsunami had an impact on Bodrum. After the earthquake, a wave height of 30-40 cm was observed on the Bodrum coast. While partial flooding occurred due to the tsunami, vehicles drifted into Gumbet, and it was determined that the tsunami climbed exactly to a height of $1.9 \mathrm{~m}$ in field observations.

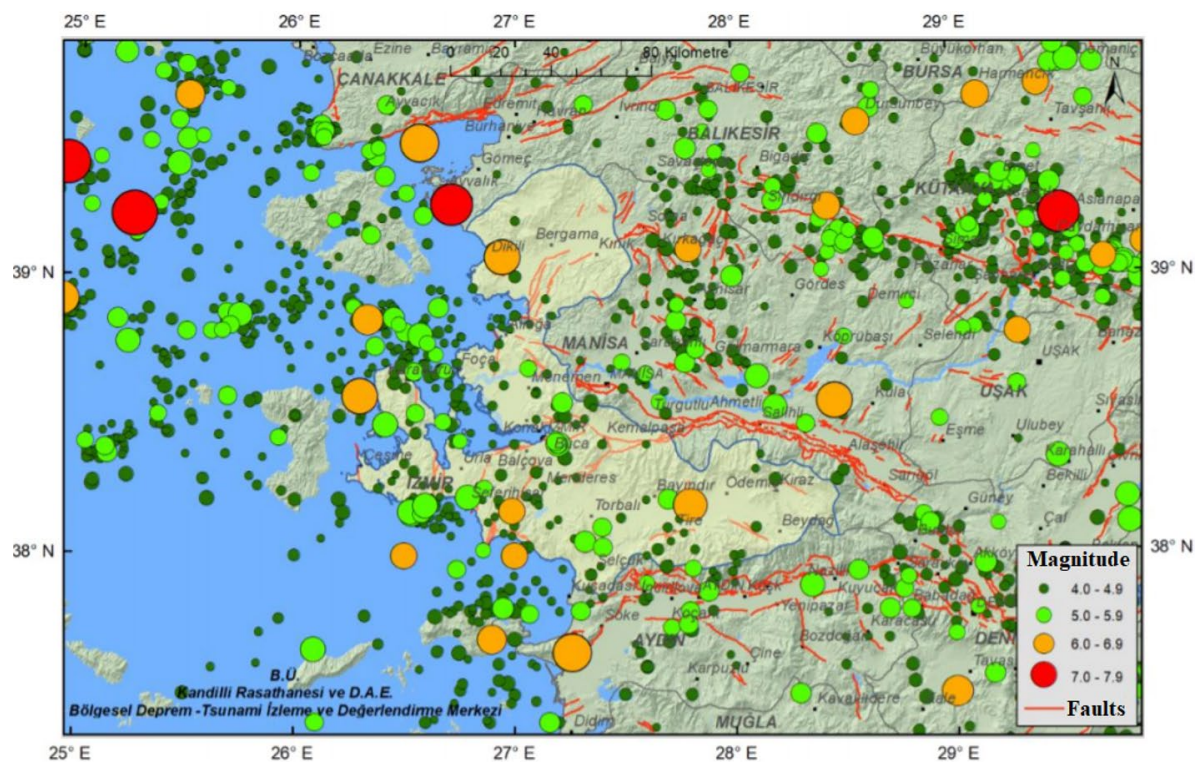

Fig. 7 Instrumental period earthquake distribution (KOERI 2020) 


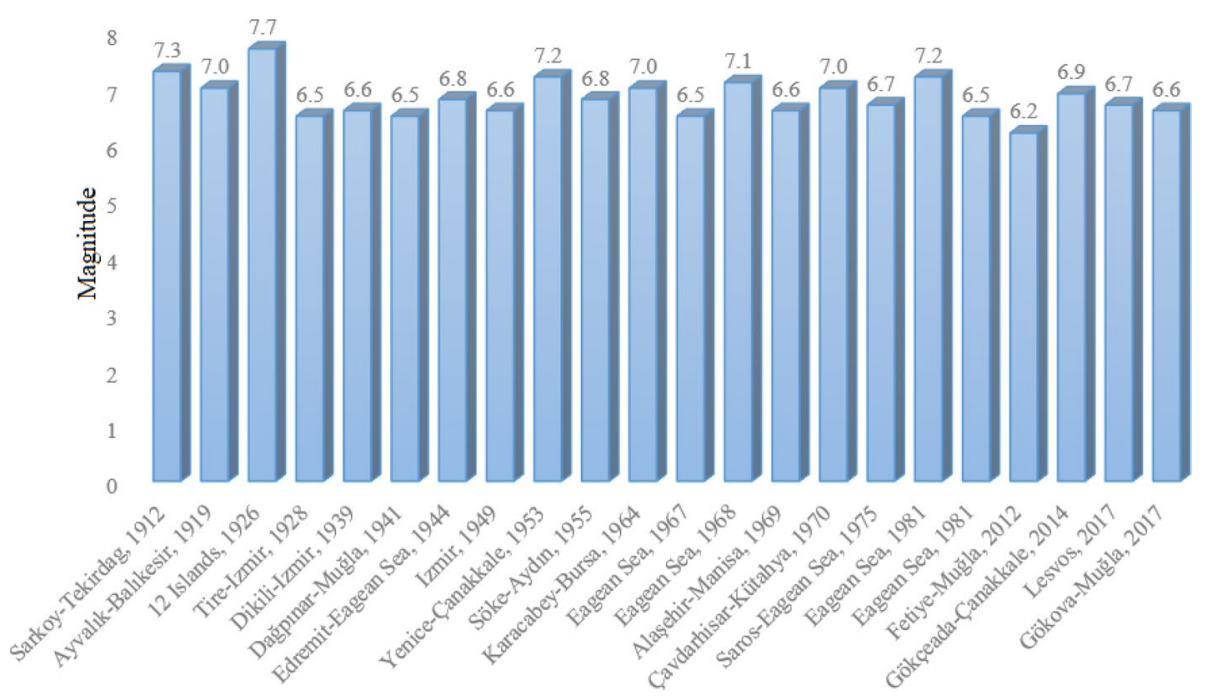

Fig. 8 Earthquakes after the year 1900 around İzmir [Plotted based on (Kiratzi 2018; KOERI 2020)]

\section{Seismic characteristics of the Samos earthquake}

The October 30, 2020, Samos earthquake was the last earthquake that occurred in the Aegean Sea region that killed people and caused severe damage to the structural systems. This ground motion and the following aftershocks were recorded by 711 accelerometers. The depth, location of the stations, and magnitude parameters of the Aegean Sea earthquake obtained from several institutions are shown in Table 1.

The ground motion relationships derived from the PGA values of the Samos Earthquake were also examined in detail in this study. Seismic activity was recorded by the five nearest stations, as illustrated in Fig. 10. Also, recorded PGA values from different stations are shown in Table 2.

Numerous institutes provided data for the Aegean Sea earthquake. However, only the Aydın-Kuşadası (0905) station provided the highest ground acceleration measurements. The greatest PGA of the earthquake was reported in the N-S direction. Three dynamic ground component accelerations, velocities, and displacement recordings acquired from Aydın-Kuşadası with recorder ID 0905 are depicted in Fig. 11. As shown, the highest ground acceleration was $144.02 \mathrm{~cm} / \mathrm{s}^{2}$ for the E-W component, $179.3 \mathrm{~cm} / \mathrm{s}^{2}$ for the N-S component, and $79.84 \mathrm{~cm} / \mathrm{s}^{2}$ for the U-D component at the Aydın-Kuşadası station.

Additionally, the highest velocity and displacement values for the N-S component were $8.93 \mathrm{~cm} / \mathrm{s}$ and $2.26 \mathrm{~cm}$, respectively. It must be stressed that the recorded PGA at Aydın-Kuşadası station did not exceed the PGA defined in the previous Turkish Earthquake Code (TEC 2007), which is equal to $0.018 \mathrm{~g}$, or the current Turkish Building Earthquake Code (TBEC 2018), which addresses a reference interval from $0.4 \mathrm{~g}$ to $0.6 \mathrm{~g}$ on the earthquake strong ground motion intensity maps. Figure 12 shows the acceleration response spectrum computed for Aydın-Kuşadası station (\# 0905) recordings with damping ratios of $0 \%, 2 \%, 5 \%$, and $10 \%$ for $\mathrm{E}-\mathrm{W}, \mathrm{N}-\mathrm{S}$, and U-D components. Figure 13 illustrates a comparison of response spectra for several soil types. 


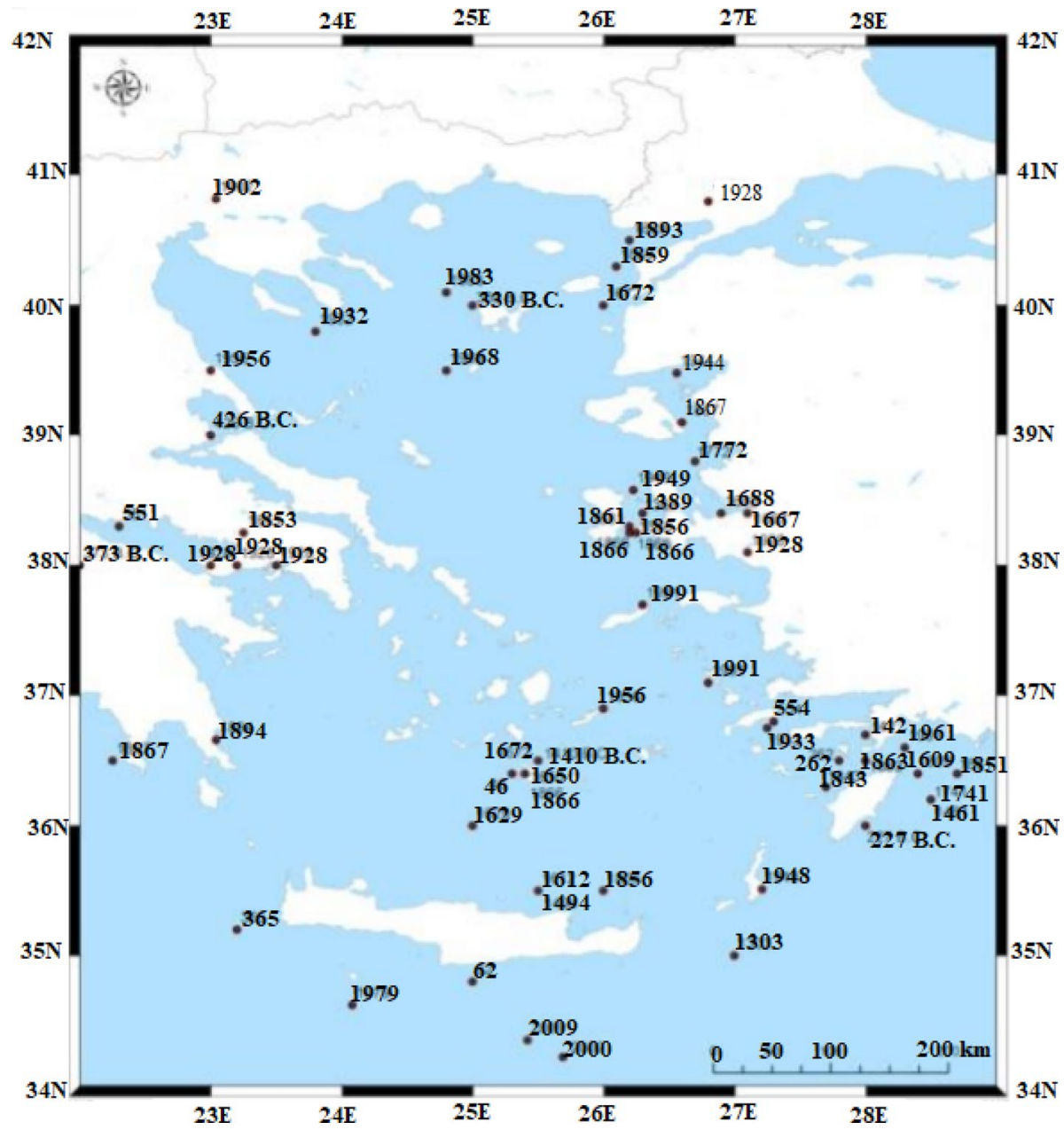

Fig. 9 Historical tsunamis and location in the Aegean Sea (KOERI 2020)

Table 1 Characteristic parameters of Samos earthquake

\begin{tabular}{|c|c|c|c|c|c|}
\hline Parameter & & DEMA $^{\mathrm{a}}$ & KOERI $^{\mathrm{b}}$ & $\mathrm{USGS}^{\mathrm{c}}$ & CSEM $^{\mathrm{d}}$ \\
\hline Magnitude $(M w)$ & & 6.6 & 6.9 & 7.0 & 7.0 \\
\hline Depth (km) & & 14.9 & 12.0 & 21 & 10.0 \\
\hline \multirow[t]{2}{*}{ Location } & Longitudinal & 37.979 & 37.90 & 37.897 & 37.91 \\
\hline & Latitude & 26.703 & 26.79 & 26.784 & 26.84 \\
\hline
\end{tabular}

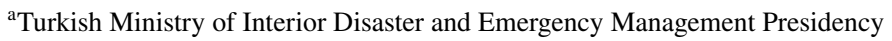

${ }^{\mathrm{b}}$ Kandilli Observatory and Earthquake Research Institute

${ }^{\mathrm{c}}$ United States Geological Survey

${ }^{\mathrm{d}}$ European-Mediterranean Seismological Centre 


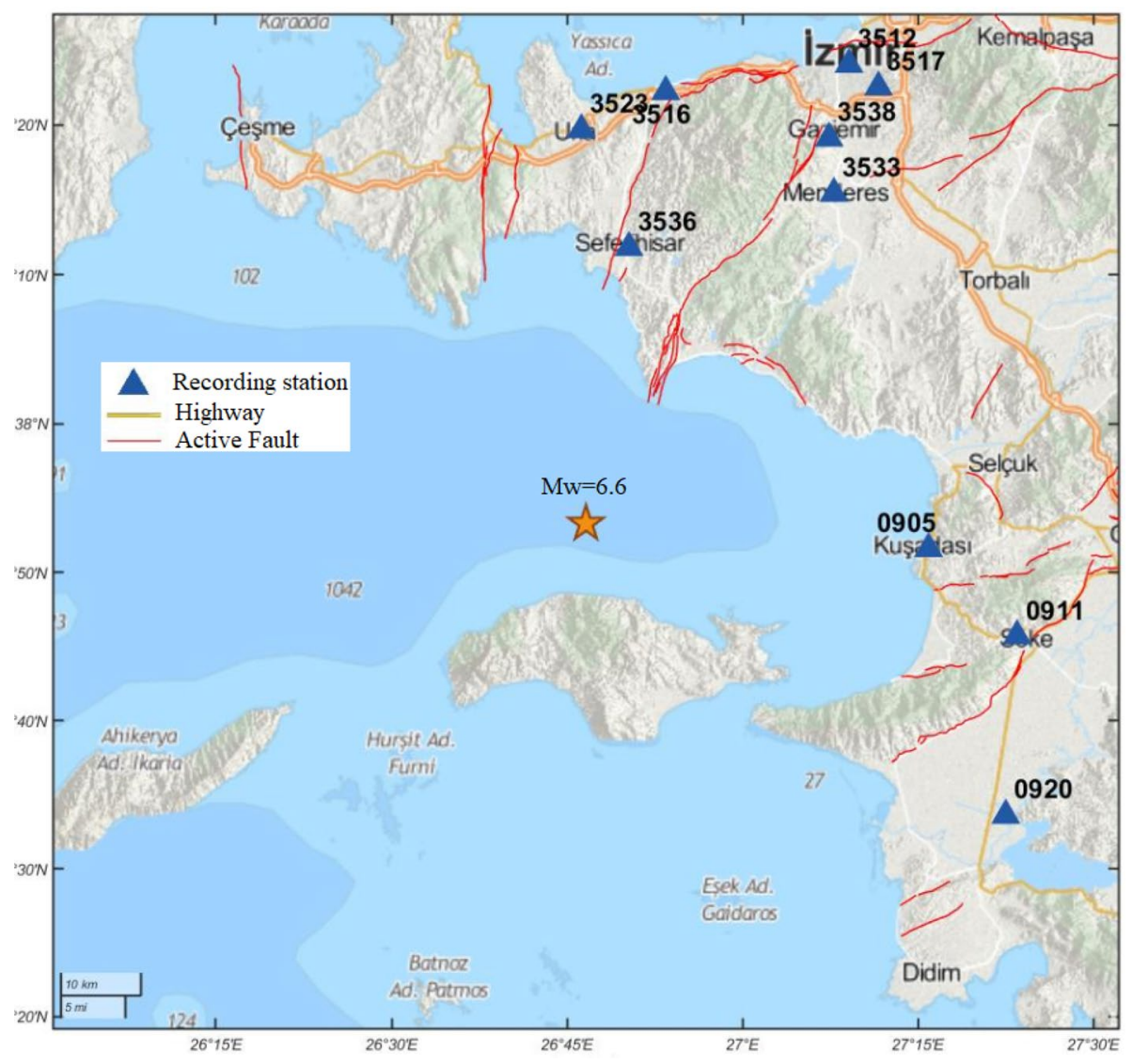

Fig. 10 Epicenter of earthquake and stations (KOERI 2020)

Table 2 Measured accelerations and physical characteristics of recording stations (KOERI 2020)

\begin{tabular}{llllllll}
\hline ID & Province & Town & Latitude & Longitude & N-S & E-W & D (km) \\
\hline 905 & Aydın & Kuşadası & 37.86 & 27.265 & 179.3 & 144.56 & 42.95 \\
3523 & İzmir & Urla & 38.3282 & 26.7706 & 82.07 & 64.95 & 48.94 \\
3533 & İzmir & Mendere & 38.2572 & 27.1302 & 73.91 & 46.43 & 51.38 \\
3516 & İzmir & Güzelbahçe & 38.3706 & 26.8907 & 47.41 & 48.54 & 54.57 \\
3536 & İzmir & Seferihisar & 38.1968 & 26.8384 & 51.03 & 81.11 & 34.75 \\
\hline
\end{tabular}

To the northeast of Samos Island, the earthquake passed through a normal fault with an East-West alignment and a dip of nearly zero. According to researchers, the earthquake broke through approximately $30 \mathrm{~km}$ of the Samos Fault on the island of Samos. Main and independent earthquakes have shorter lengths in the east and west portions of the main fault on Samos (indicating an average evidence of normal faulting) (DEMA 2020). The distribution of aftershocks in the 62 days following the earthquake evolved to confirm the 


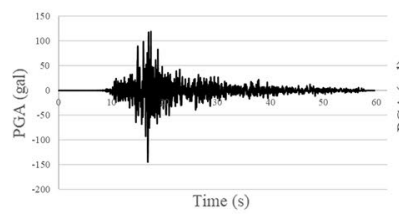

(a) $\mathrm{E}-\mathrm{W}$

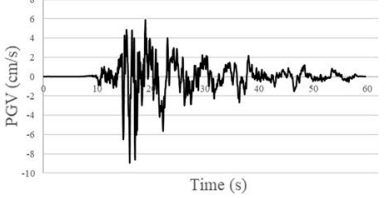

(d) E-W

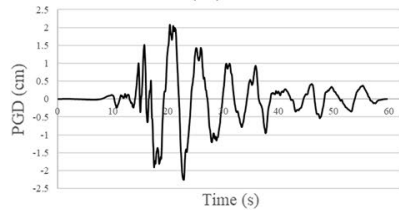

(g) E-W

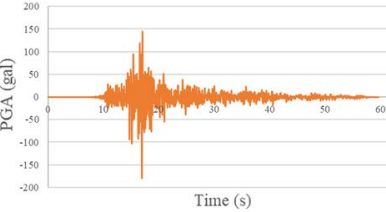

(b) N-S

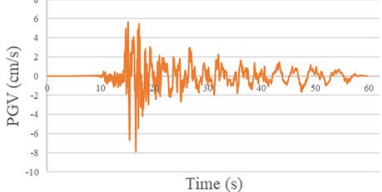

(e) N-S

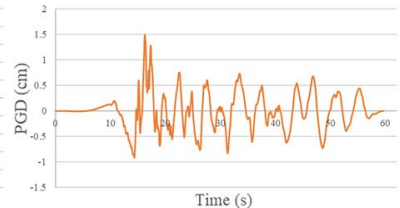

(h) N-S

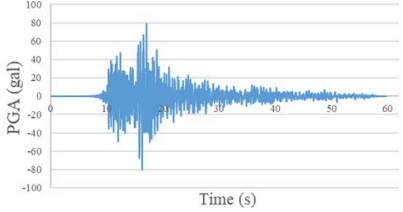

(c) U-D

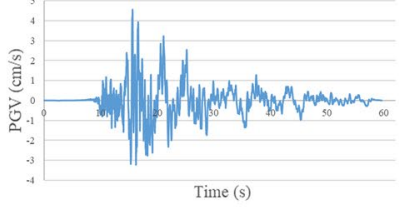

(f) U-D

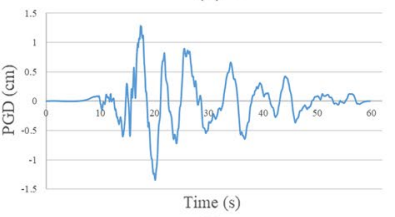

(i) U-D

Fig. 11 a-c Acceleration, d-f velocity and $\mathbf{g}$-h displacement time histories

obtained map of stress distribution. According to the most recent report from the Kandilli Observatory and Earthquake Research Institute (KOERI 2020), during the first 30 days following the mainshock, 60 earthquakes with a magnitude greater than 4.0 and 5068 aftershocks with a magnitude from 0.8 to 5.2 occurred (Fig. 14).

\section{Basin effect}

The province İzmir is located on İzmir bay. Most of the city is constructed on the Bornova basin. This area has two generations of stacked or superimposed basins. The term "superimposed basins" refers to a basin type that comprises at least two sediment fills with contrasting ages, origins, facies, internal structures, and deformation patterns. The major geological units for the stratigraphy are as follows: (a) the Late Cretaceous-Paleocene basement area and (b) the Miocene older basin fill overlain by (c) the Plio-Quaternary younger basin fill (Fig. 15a). The Bornova melange serves as the geological foundation for the area, with Mesozoic limestones, cherts, underwater volcanics, and serpentinites contained in a flysch-type sedimentary matrix (Makra et al. 2021). Bornova melange is the oldest geological unit in the world. As an unconformity, Neogene-aged sedimentary rocks are included into the Bornova melange. Pebbles, argillaceous limestones, and silicified limestone comprise these sedimentary rocks. Volcanite forms an unconformity over the Neogene sedimentary strata (Pamuk et al. 2018). A geological formation of İzmir is demonstrated in Fig. 15a.

From a tectonic perspective, the Bornova basin is bordered to the south by the İzmir fault zone (FZ). The FZ is a 40-km long, E-W trending, active normal fault transition zone. It is approximately $2-4 \mathrm{kms}$ broad and $2 \mathrm{kms}$ long. The northern half of the basin is bounded by the Karşyaka fault zone (KFZ), which is the polar opposite of the FZ. 
Fig. 12 Acceleration response spectra for North-South, EastWest and vertical components of Aydın-Kuşadası (\#905) station acceleration records

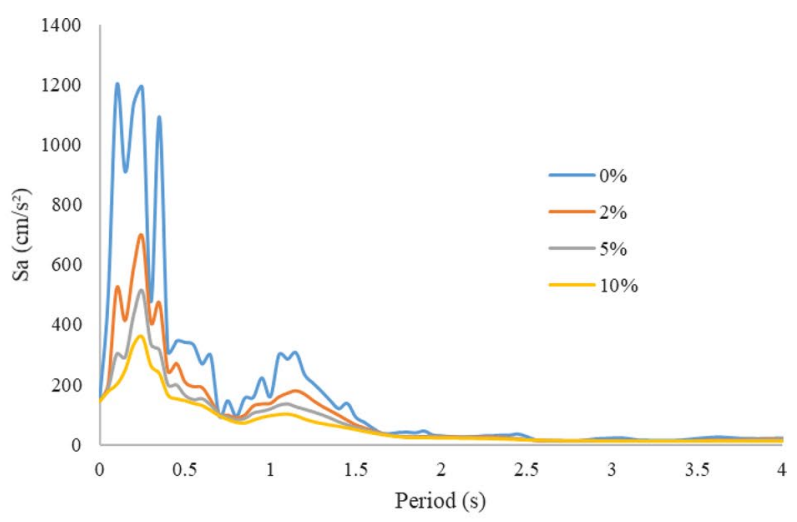

(a) E-W component

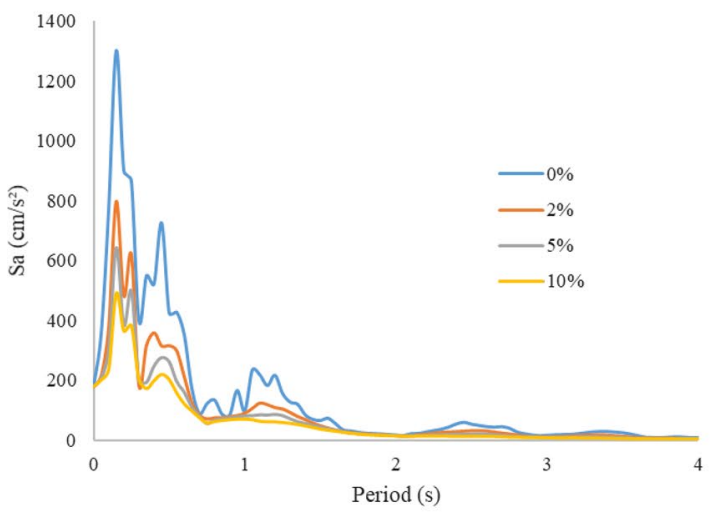

(b) N-S component

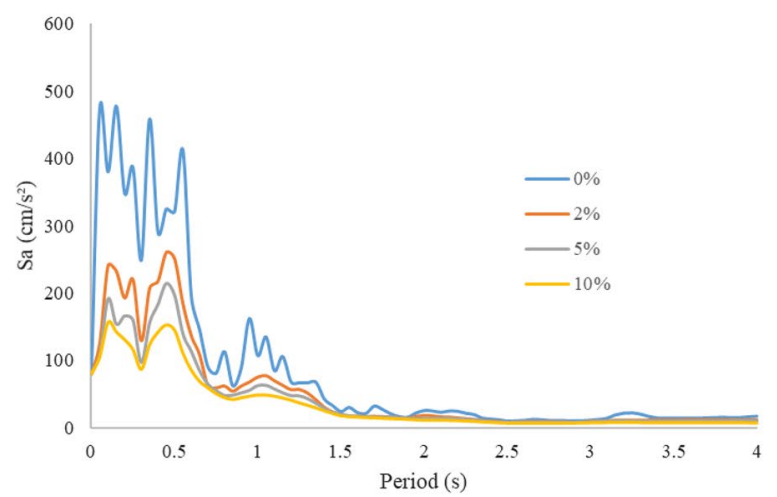

(c) U-D component

The KFZ is a roughly E-W trending normal fault transition zone measuring from 0.5 to $2.5 \mathrm{~km}$ in breadth and $20 \mathrm{~km}$ in length with a well-developed steplike morphology. Both the KFZ and IZF include recent basin fill units, whereas the footwall is stratified by volcano sedimentary rock layers from the earlier basin fill (Makra et al. 2021). Two 


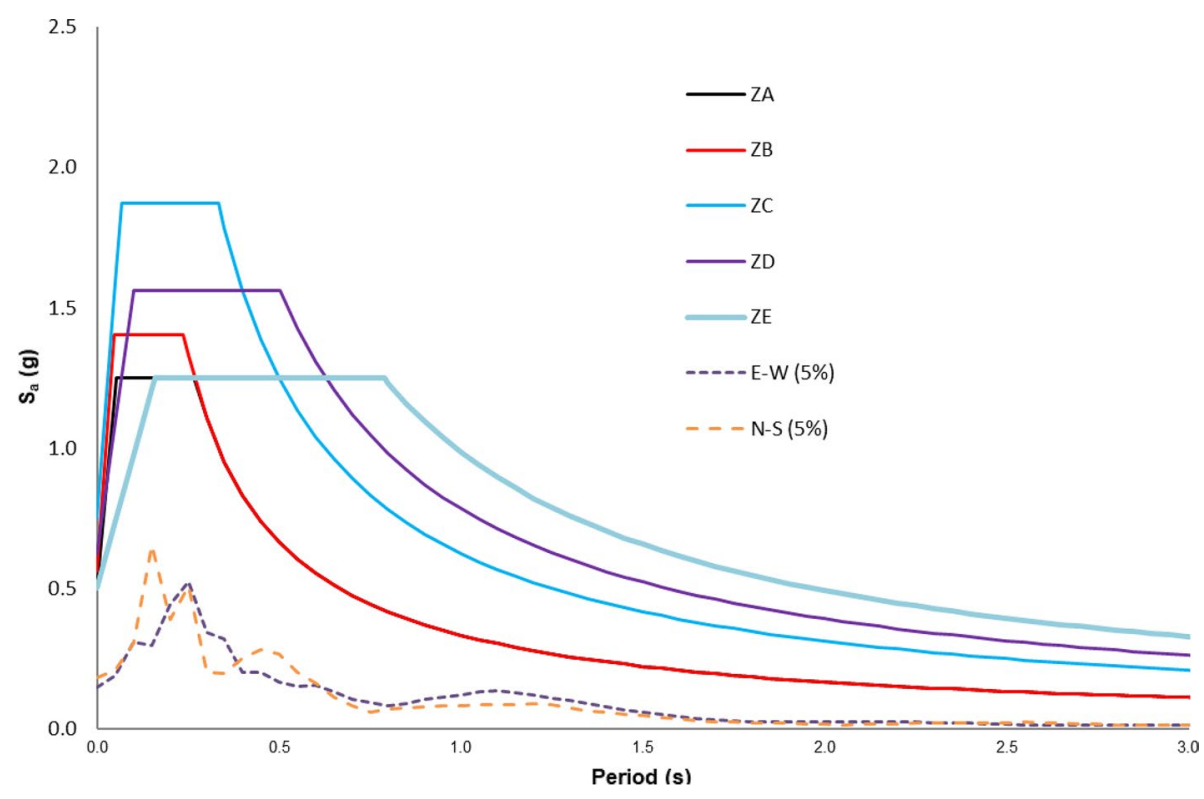

Fig. 13 Comparisons of acceleration response spectra with the design spectra Aydın-Kuşadası station record (\#0905)

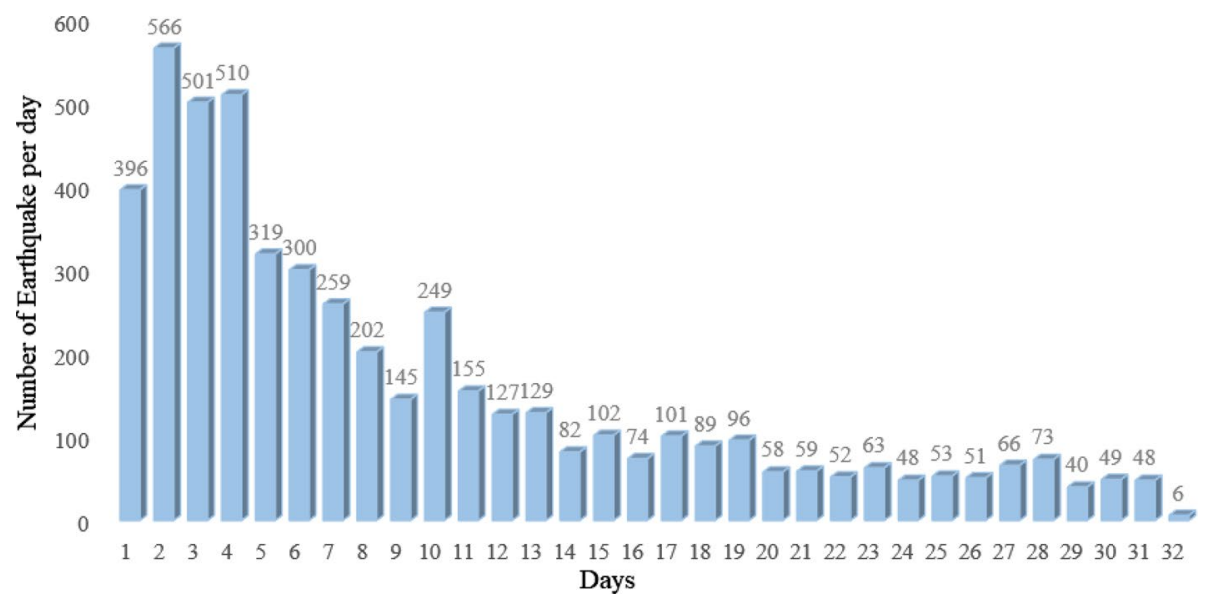

Fig. 14 Distribution of number of aftershocks after main shock (KOERI 2020)

significant morphological characteristics are readily apparent: the high bedrock outcrops and the low-lying basin structure with heavy sedimentary deposits. A sizable portion of the urban area of İzmir is built on sedimentary alluvial deposits. Additionally, considerable fluvial deterioration occurs in the Gediz River delta in the northern area of the Bay of Izmir. Site reaction was critical in amplifying ground vibrations on soft soil sites, such as at station areas 3513, 3518, 3519, 3521, and 3522 during the October 30, 2020, earthquake (Fig. 15b). 


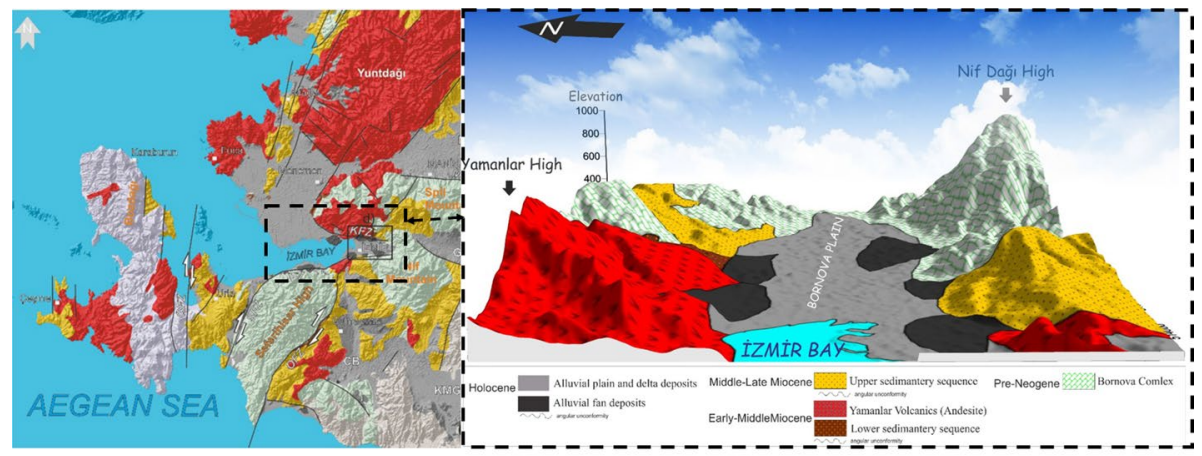

(a) Geological units of Bornova plain [Modified from (Pamuk et al. 2018)]

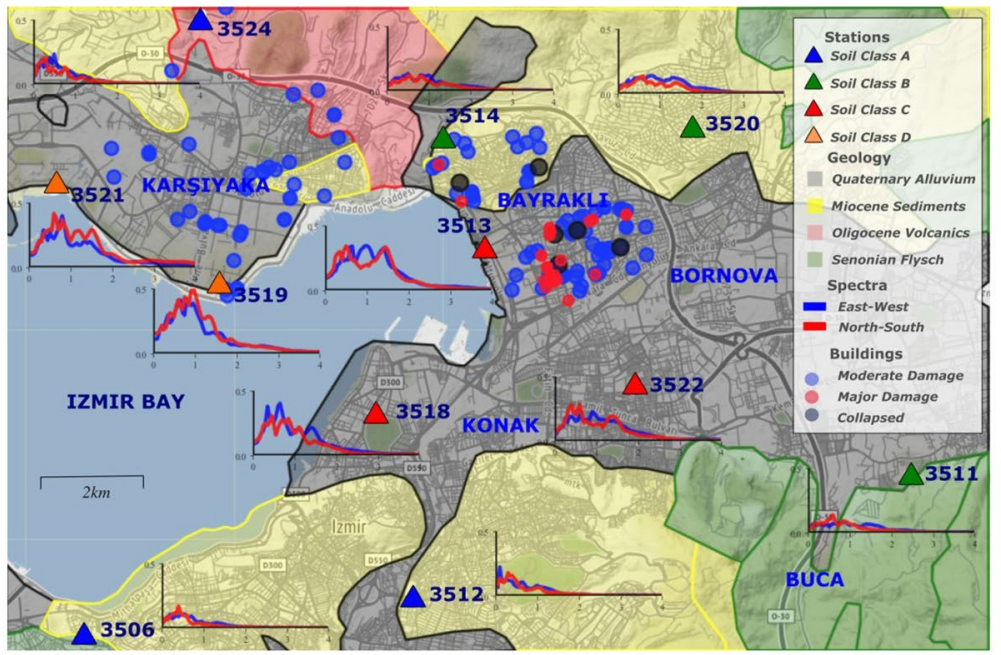

(b) Response spectrum distribution according to geology and damage distribution according to geology [Numbers in the figures demonstrates AFAD seismic stations (Akinci et al. 2021)]

Fig. 15 Geologic properties of İzmir metropolitan city territory, damage and response spectrum distribution

Ground motion relationships for the PGA values of the Samos Earthquake were also used in this study for a detailed investigation. Two of the latest ground motion models by Akkar et al. (2014) and Erken et al. (2018) were considered and plotted in Fig. 16 for the E-W and N-S directions by employing 51 station records. The ground motion models were evaluated for both the E-W and N-S components of the earthquake and are plotted in the same figure. As presented in the figure, the commonly used latest ground motion models were used for Europe and the Middle East. Moreover, both equations were slightly overestimated due to the basin effect. As shown in Fig. 16, a strong ground motion prediction was recorded at the stations closest to epicentre provided data with a lower accuracy due to basin effect.

The basin effect and alluvial soil profiles alter the behaviour of the measured seismic waves to an unpredictable level. To see the differences between the predicted and 


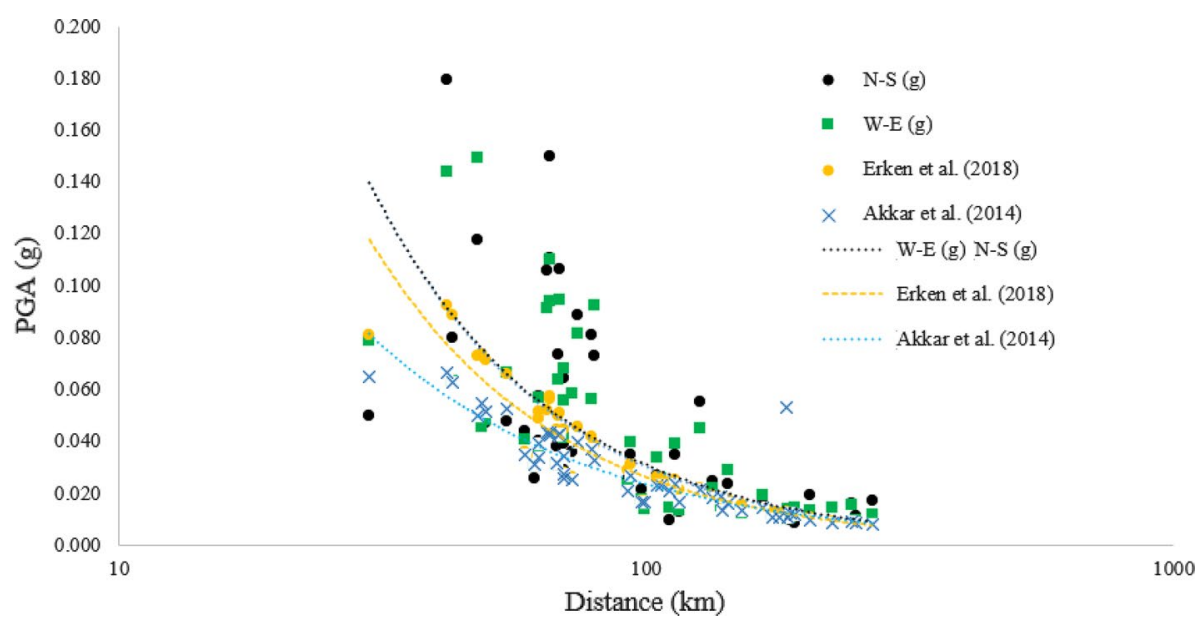

Fig. 16 The PGA and distance relationship for Samos earthquake along $250 \mathrm{~km}$

measured PGA values from the stations, root mean square (RMSE) values were calculated as a prediction indicator. The basic aim was to calculate the RMSE to determine which soil profile during the Samos earthquake altered the seismic behaviour. RMSE values are commonly used to determine the degree of error between two data sets. For this study, the data sets included the measured PGA data from the station and predicted PGA data. The closer the RMSE value is to zero, the better the prediction capability of the model. The RMSE value was calculated as follows using Eq. 1.

$$
\mathrm{RMSE}=\sqrt{\frac{1}{n} \sum_{i=1}^{n}\left(y_{\text {measured }}-y_{\text {predicted }}\right)^{2}}
$$

As shown in Fig. 17, there are four different soil types distributed along the İmir metropolitan city territory from ZB to ZD according to the TBEC 2018. A batch of 51 different stations, with both N-S and E-W components, were evaluated. The RMSE values presented in Fig. 17 indicate that the closest prediction was provided by Erken et al. (2018) in the W-E direction. The N-S prediction obtained by using the equation provided by Erken et al. (2018) was slightly overestimated. However, the equation provided by Akkar et al. (2014) provided a closer prediction in the W-E direction but was a bit high in the N-S direction for overall evaluation of the equations. Four different soil types were evaluated separately to determine the deviation due to basin effect. The highest differences were obtained from the ZE soil type. The high RMSE value was related to the limited data. Most of the stations were located on the territory classified as ZC and ZD. Even if ZD was classified as a one of the worst soil types, the prediction accuracy was lower than that for ZC due to the large number of data points and average distance from the epicentre. A total of 25 stations were evaluated, and the average distance from the epicentre was $139 \mathrm{~km}$. Even if there is a limited amount of data related to ZB soil, the proposed equations were predicted with the highest accuracy, especially those from Akkar et al. (2014) in the N-S direction. 


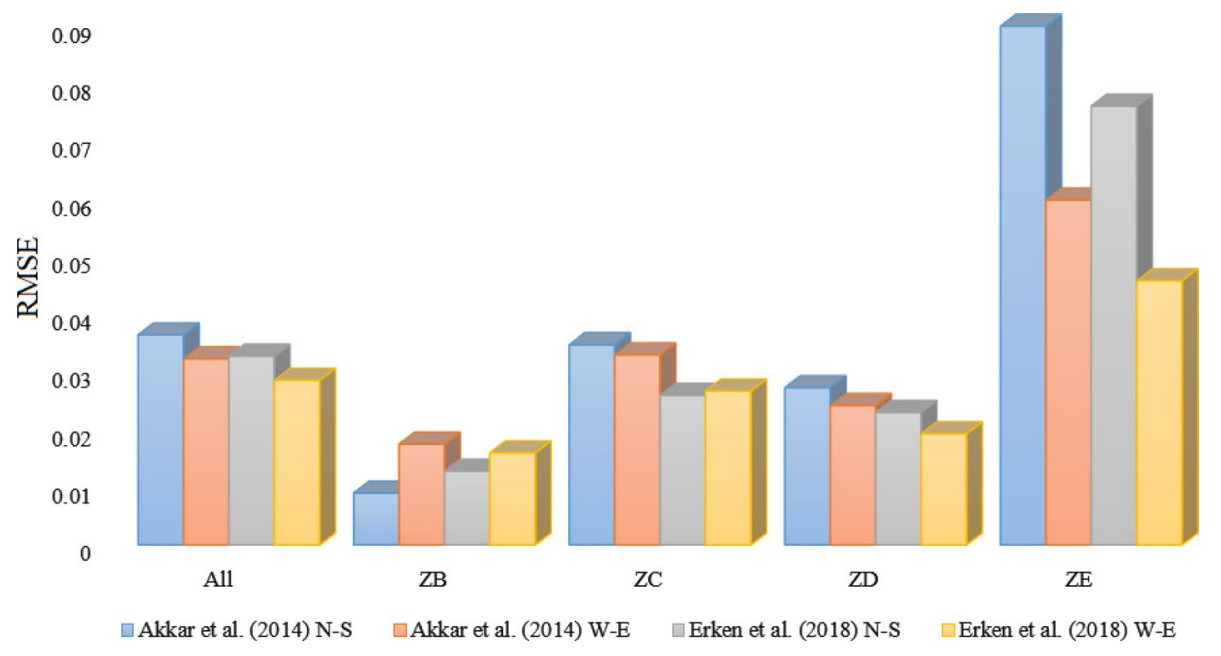

Fig. 17 Calculated RMSE value for different soil types

\section{Overview of building stock in İzmir province}

In the aftermath of the İzmir earthquake, many of the apartment buildings that were turned into rubble were next to residences that remained intact or only suffered cracks, which raised questions about their state prior to the disaster that killed 114 people. This situation forced researchers to investigate the building stock portfolio of İzmir. Most of the collapsed buildings were built more than two decades ago, before the regulations mandating sturdier construction were established following a deadly earthquake in 1999 in northwestern Turkey. All fatalities in the earthquake were in nine buildings in the Bayraklı district, which collapsed either entirely or partially (URL2). There were about 670 thousand buildings available in İzmir, and $89 \%$ of the building stock was used for residential purposes. The building stock portfolio distribution is shown in Fig. 18.

As shown in Fig. 19, the building stock portfolio in İzmir is divided into three categories: reinforced concrete, masonry dwellings, and others (steel and wood).

Before presenting the performance assessment, it is important to note that the number of floors has a significant impact on the earthquake behaviour and vulnerability assessment of all structures, particularly reinforced concrete buildings. These are structures constructed

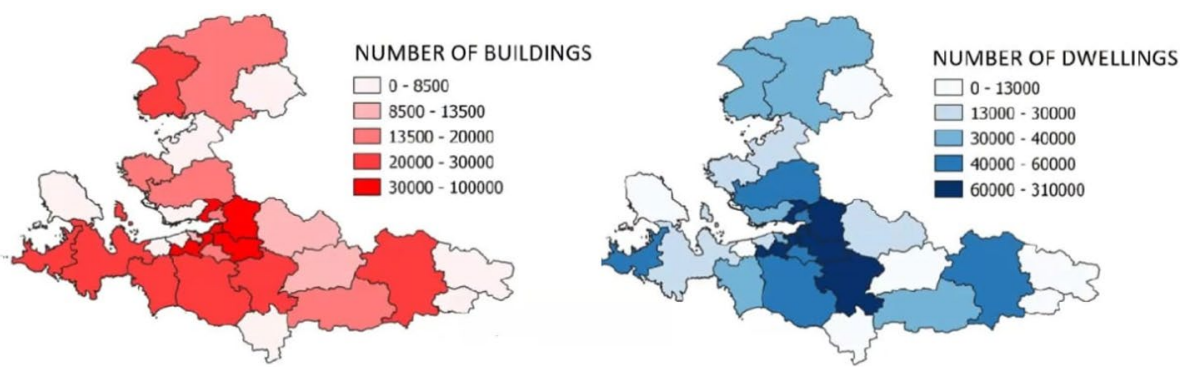

Fig. 18 Building stock distribution in İzmir (METU 20200) 
Fig. 19 Main bearing elements of building portfolio of İzmir (METU 2020)

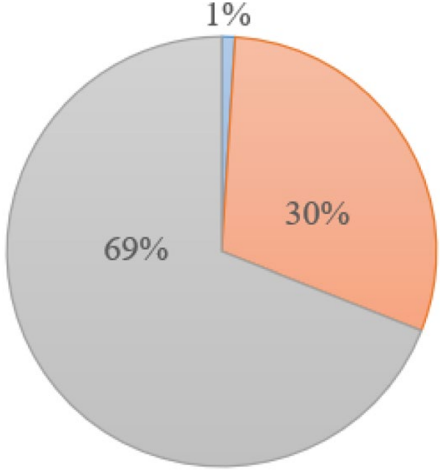

$\square$ Others $\quad \square$ Masonry dwellings $\quad \square$ Infilled RC

prior to 1980, structures constructed between 1980 and 2000, and structures constructed after 2000. In this regard, reinforced concrete structures in Izmir are also classified by their floor numbers. Building groups with 1-3 stories (referred to as low-rise buildings), 4-8 stories (referred to as mid-rise buildings), and 9 stories and above (referred to as high-rise buildings) were classified based on the performance of reinforced concrete structures in Turkey during prior earthquakes. Figure 20 depicts the percentage of reinforced concrete structures classified by floor number and construction year in İzmir. Mid-rise building data were obtained between 1980 and 2000, making it particularly sensitive. The data indicate that reinforced concrete constructions accounted for $11 \%$ (more than 50,000 structures) of all reinforced concrete structures in İzmir. In this context, reinforced concrete buildings in İzmir were also classified according to the number of floors, as shown in Fig. 20.

Figure 20 analyses the proportional change in the total number of buildings produced in İzmir during an approximately ten-year period. The data indicate that the number of buildings in İzmir increased quickly between 1980 and 2000, accounting for more than $40 \%$ of the current building stock. Previous earthquakes in Turkey indicated that structures of this age are one of the most vulnerable segments of the Turkish building sector. It has been demonstrated that this circumstance holds true for İzmir as well.

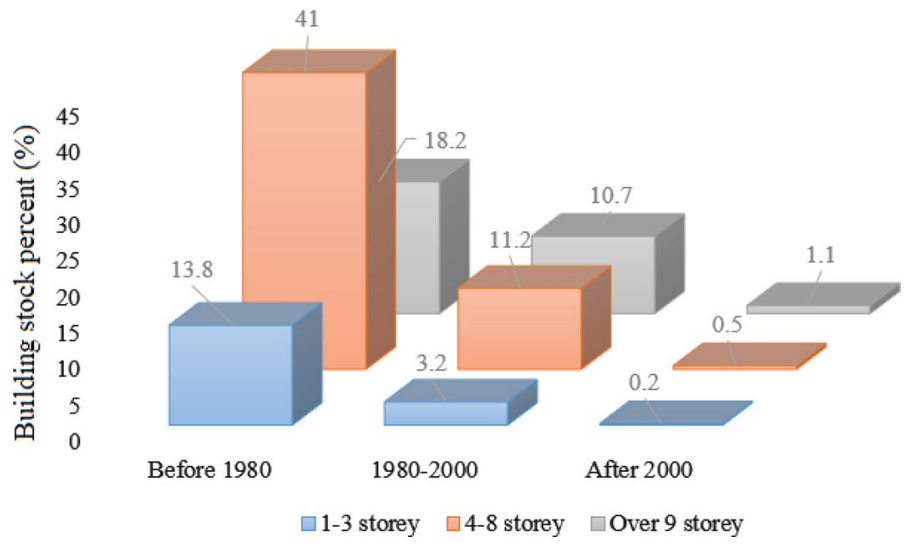

Fig. 20 Distribution of building storey number vs. construction year (METU 2020) 
Table 3 History and development of seismic codes in Turkey (Keskin and Bozdoğan 2018)

Name of the seismic code

Date of

imple-

mentation

Italian Building Code for Construction in Earthquake Zones (Keskin and Bozdoğan 2018)

1940

Temporary Building Regulations in Earthquake Zones (Keskin and Bozdoğan 2018)

1944

Turkey Building Regulations for Earthquake Zones (Keskin and Bozdoğan 2018)

1949

Regulations Governing the Construction of Structures in Earthquake Zones (Keskin and

1953

Bozdoğan 2018)

Regulations Governing the Construction of Structures in Disaster Areas (Keskin and Bozdoğan 1962 2018)

Regulations Governing the Construction of Structures in Disaster Areas (TSC1968)

Regulations Governing the Construction of Structures in Disaster Areas (TSC1975)

Regulations Governing the Construction of Structures in Disaster Areas (TSC1998)

1998

Regulations for the Construction of Buildings in Earthquake Zones (TSC2007)

2007

Turkey Building Seismic Code (TBEC2018)

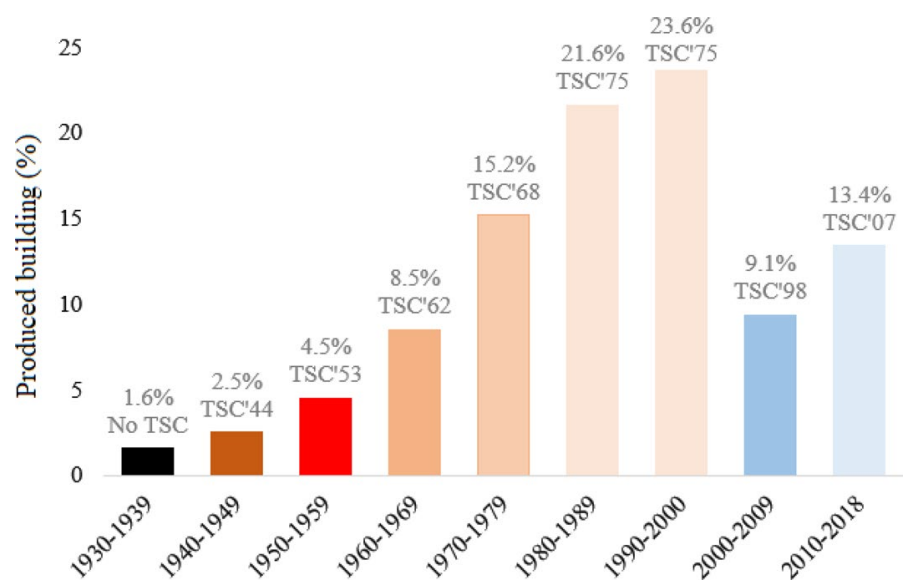

Fig. 21 Produced building per cent and seismic codes between 1930-2019 [Modified from (METU 2020)]

There are nine seismic codes that were published before the current seismic code in Turkey. The history of the seismic codes is shown in Table 3.

The first seismic code in Turkey was implemented in 1940 and was based on the Italian seismic code. Then, the current seismic code, called the Turkey Building Seismic Code 2018, was the tenth seismic code currently in use in Turkey. Figure 20 compares the distribution of building production ratios according to considered seismic codes during the production of the total number of buildings produced in Izmir over a period of about 80 years. Additionally, Fig. 21 demonstrates that over $77.5 \%$ of the building stock in İzmir was not constructed in a manner consistent with the modern seismic code / building inspection (METU 2020).

The data reveal that the number of buildings in İzmir increased quite rapidly between 1980 and 2000, and more than $40 \%$ of the existing building stock was built within this 20 -year period. In addition, these buildings were constructed according to seismic codes 
published in 1975. More extensive seismic codes were published in 1997. Only $9.1 \%$ of these buildings were produced according to this seismic code. The next seismic code was published in 2007 , and $13.4 \%$ of the buildings were produced according to this code. Previous earthquakes in Turkey indicate that buildings of this age are one of the building groups with the highest vulnerability in the Turkish building stock. Figure 21 also shows that more than $77.5 \%$ of the building stock in Izmir was not built in accordance with the modern earthquake code (METU 2020).

\section{Damage assessment of reinforced concrete buildings}

Reinforced concrete buildings constitute most of the building stock in Turkey. Migration from rural areas to cities has resulted in rapid reinforced concrete construction. This uncontrolled rapid construction has caused the proliferation of poor-quality buildings that are not earthquake resistant. Considerable damage occurred to reinforced concrete structures during the October 30, 2020, earthquake. The main problems with the damaged structures were conventional concrete pouring; the use of ready-mixed concrete, which started after the 1999-Kocaeli earthquake; insufficient transverse reinforcement; poor workmanship; corrosion due to the use of sea aggregate; and structural deficiencies resulting from architectural mistakes.

The studies that investigated the causes of damage by observing the structural damage that occurred after earthquakes and offer solutions contribute significantly to the literature. As a result, since the 1999 Kocaeli earthquake, researchers have taken a keen interest in such published studies (Saatcioğlu et al. 2001; Sezen et al. 2003), such as for the 2003 Bingöl earthquake (Doğangün 2004), 2011 Simav earthquake (İnel et al. 2013; Yön et al. 2013), 2011 Van earthquakes (Taşkın et al. 2013; Yön et al. 2015; Yön et al. 2019), 2017 Mexico earthquake (Tena-Colunga 2021), and 2020 Sivrice earthquake (Sayın et al. 2021; Yurdakul et al. 2021; Demir et al. 2021; Altunışık et al. 2021).

Damage to reinforced concrete buildings was assessed in detail in this section in accordance with the requirements of the Turkish Seismic Codes from 1975, 1997, 2007, and 2018. The structural elements observed by the technical team can be listed as follows:

- Insufficient transverse reinforcement in structural members.

- Short column failures.

- Inadequate gaps between adjacent buildings.

- Strong beam-weak column.

- Poor concrete quality and corrosion.

- Failures of gable walls.

- Damage to infill walls.

\subsection{Insufficient transverse reinforcement in structural members}

Brittle fractures that occur from shear forces cause great damage and losses, both for the element and structural system. Ensuring shear safety is very important for structural performance, especially under forces that can vary in magnitude and direction, such as earthquake forces. Compressive, friction, and tensile forces in the reinforcements in the bearing elements of reinforced concrete structures create forces that resist shearing. However, shear resistance in structural members is mainly provided by transverse reinforcements. 
Therefore, it is necessary to pay attention to the design and construction of these members. Confinement of transverse reinforcements increases the ductility of the structural member and the compressive strength of the concrete by creating lateral forces under axial loads. Although there are requirements for stirrup tightening even in the 1975 (TSC 1975) earthquake code, this criterion was not considered for columns and beams. During the field observations, the spacing of the ties in columns ranged from approximately $25-40 \mathrm{~cm}$. The wide spacing of the transverse reinforcements between other reinforcements caused buckling of longitudinal rebars, spalling off the concrete cover, and causing shear failures. But, according to the codes from 1975 to 2018, the maximum tie spacing should not exceed $150 \mathrm{~mm}$ in confinement zones (Fig. 22). However, special seismic cross ties and hooks should be bent to $135^{\circ}$. However, the transverse and longitudinal bars of the damaged columns and beams were smooth and $90^{\circ}$. In the observed buildings, it was seen that necessary care was not given to designing longitudinal reinforcement bars, and a sufficient number of transverse bars was not used in the columns and beams. Figure 23 shows damaged structural elements in buildings due to inadequate transverse reinforcement and the use of improper hooks and smooth bars.

Beams are damaged by deficiencies like columns. Insufficient longitudinal and confinement reinforcement and a low concrete strength caused brittle fractures in beams. While the longitudinal tensile reinforcement ratio $(r \leq 0.005)$ is for unribbed reinforcement (for S220) in the 1975 earthquake code, it is given as $(r \leq 0.002)$ for ribbed reinforcement (for S420) in the 1997, 2007, and 2018 codes (Fig. 24). When the damaged beams were evaluated, it was seen that even the conditions given for the beams in the 1975 regulation were not met. Figure 25 shows damaged beams resulting from the September 30, 2020, Aegean Sea earthquake.

\subsection{Beam-column joints}

Reinforced concrete buildings are unlikely to collapse wholesale under vertical loads. The main problem is forces, such as from earthquakes, that stress the structure in the horizontal direction. The resistance of earthquake forces is possible by the safe transfer of these loads to columns. The first elements that meet the horizontal load in a structure are the elements that combine with the joint. The higher the stiffness of these points is, the safer the transfer of the load to the columns. These joints play a critical role in the distribution of force.

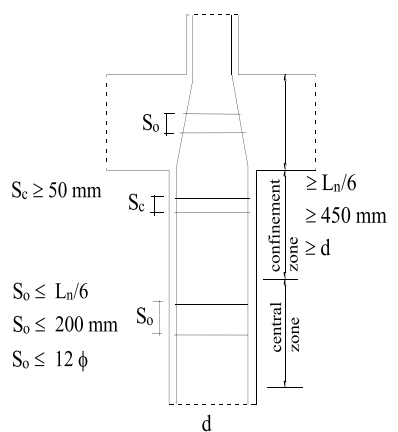

(a) TSC-1975

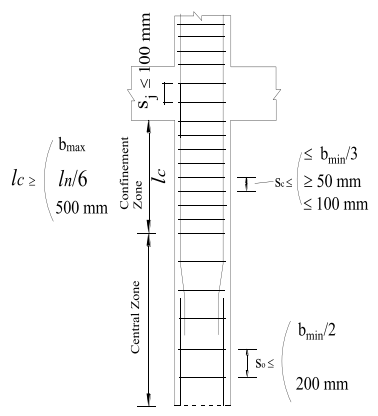

(b) TSC -1997; TSC-2007

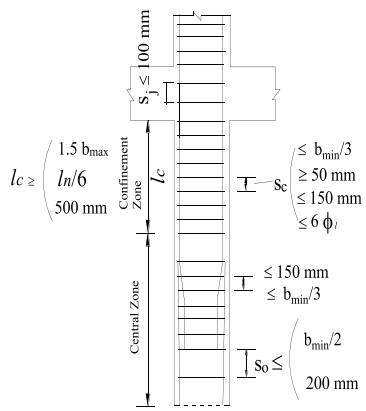

(c) TSC-2018

Fig. 22 Turkish Seismic Code requirements for columns 


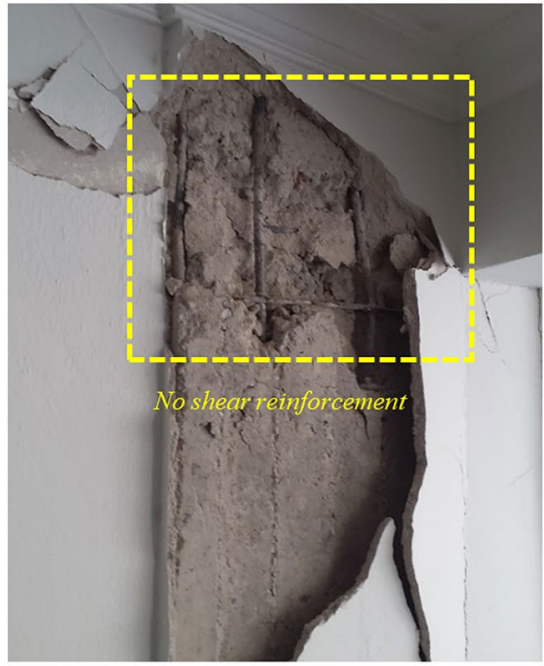

(a) $38.4568064270,27.1888068236$

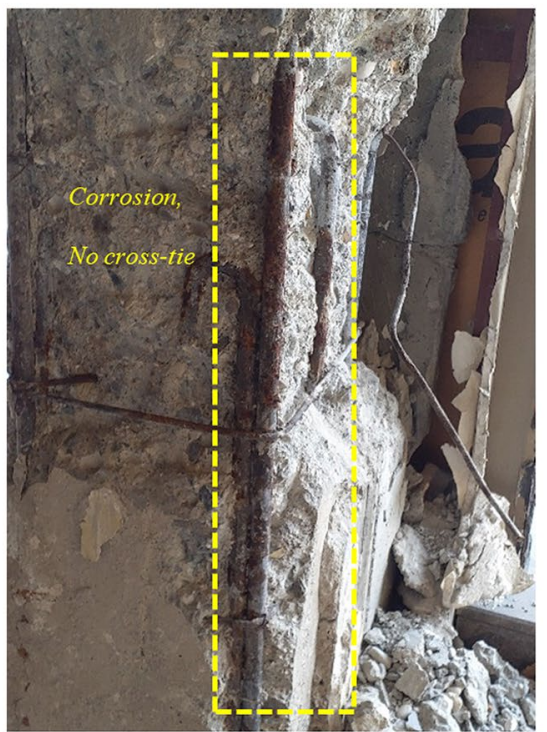

(c) $38.4246728378,27.1329212225$

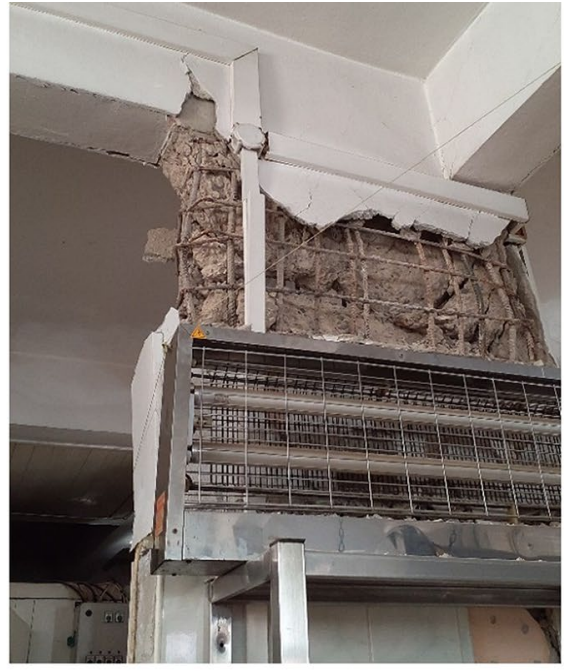

(b) $38.4529011521,27.1805814377$

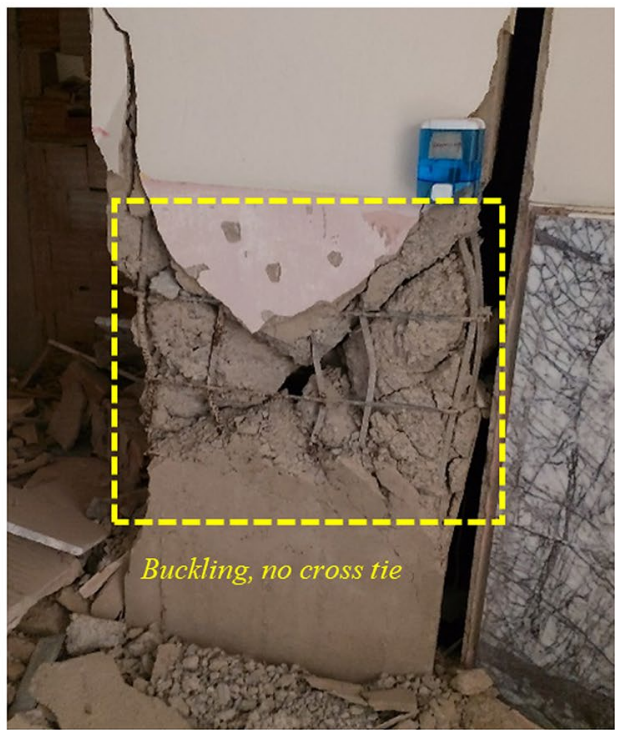

(d) $38.4632769521,27.1898362000$

Fig. 23 Damaged structures due to inadequate spacing between shear reinforcements during the Aegean Sea earthquake

Even if the columns of the building system are strong, the structure can become a mechanism and partially or completely collapse in cases such as cracking and disengagement of the anchorage at the joints. During the Aegean Sea earthquakes, many RC buildings were severely damaged due to failures of these joints. It was determined that weak detailing of beam-column joints and the use of materials with a low quality were the main reasons for the damage. However, a lack of transverse and seismic cross ties and inadequate anchorage 


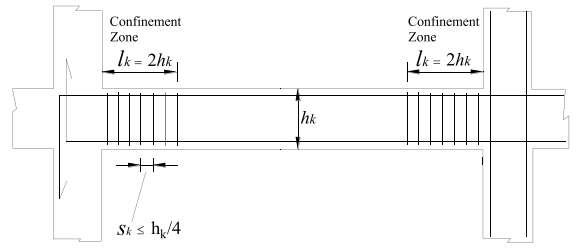

(a) TSC 1975

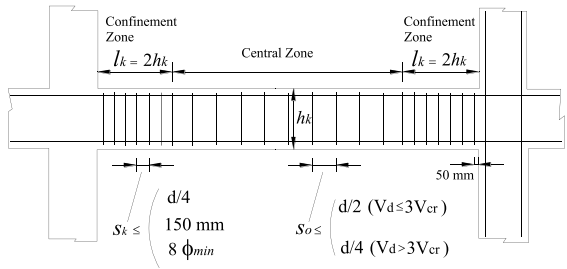

(b) TSC 1997; 2007 and 2018

Fig. 24 Requirements for beams according to various Turkish Seismic Codes

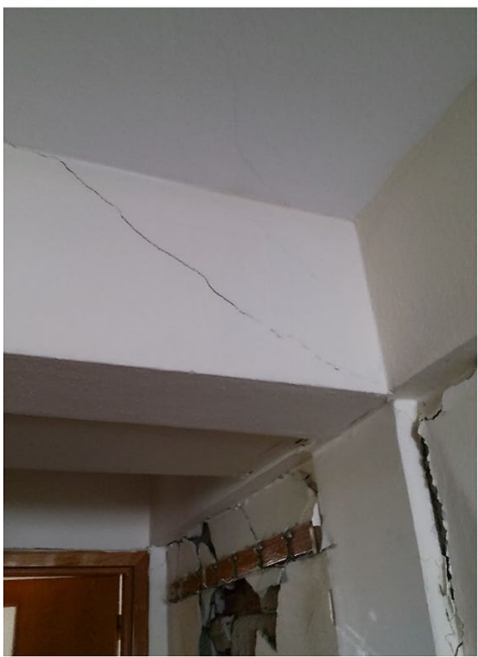

(a) $38.45333,27.19040$

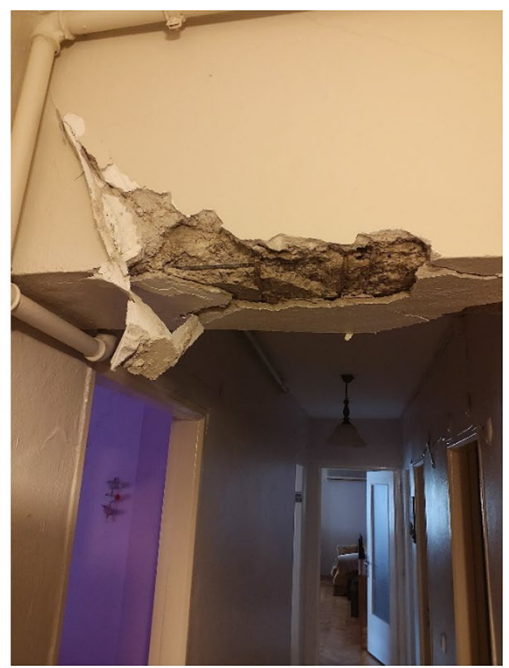

(b) $38.46448,27.19034$

Fig. 25 Damaged beams during the September 30, 2020, Aegean earthquake

bars for the beams and columns in reinforced concrete elements lead to joint failure. Figure 26 depicts various types of damage. To protect joints from damage, sufficient confinement and shear reinforcement should be used with special attention paid to the design of these elements.

\subsection{Short columns}

Ribbon windows are made on the upper parts of infill walls for illumination in basements of schools, hospitals, and buildings, and these are not taken into consideration during the design phase. Although this design was not included in the project, it can also be done by the residents later. In such a case, the columns are supported by an infill or shear wall up to the bottom of the window. Thus, the length of the columns whose sides are unloaded decreases and the rigidity increases. Since an earthquake load is shared according to the stiffness of the columns, these extremely rigid columns are exposed to much more than the shear force that was calculated during the design. Shear fractures occur in columns that are not designed according to this load. Since the earthquake is a dynamic and reversed-cyclic 


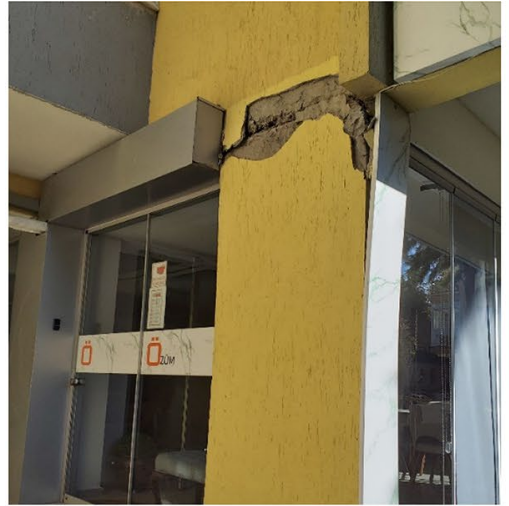

(a) $38.4583019854,27.19142350$

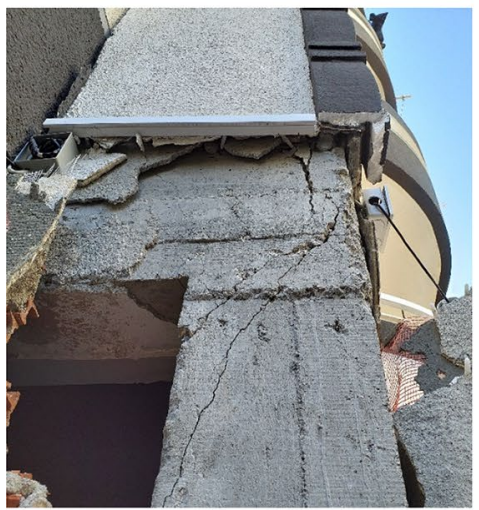

(c) $38.4610308123,27.1856894235$

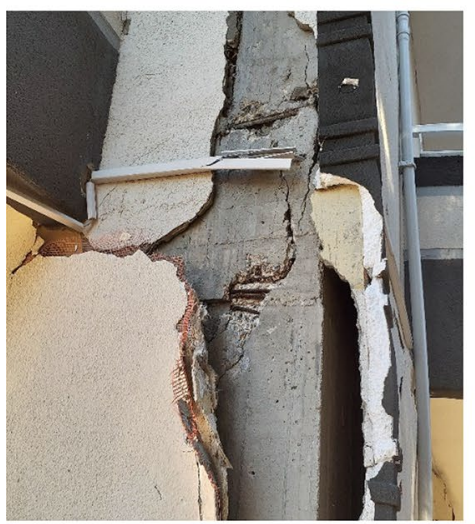

(e) $38.4610308123,27.1856894235$

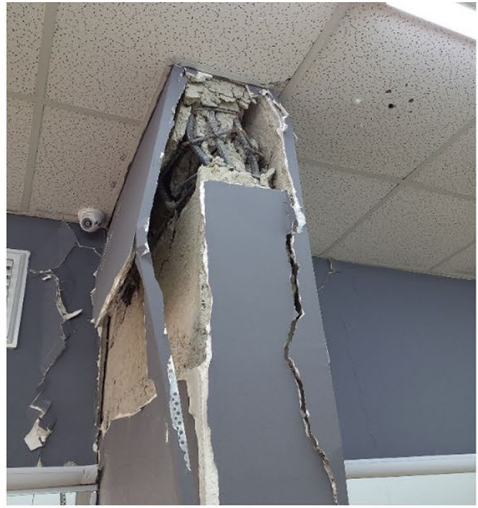

(b) $38.4541639803,27.1809567197$

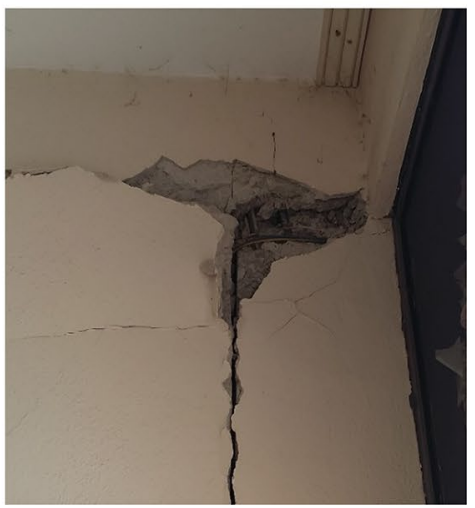

(d) $38.4556947741,27.1919766284$

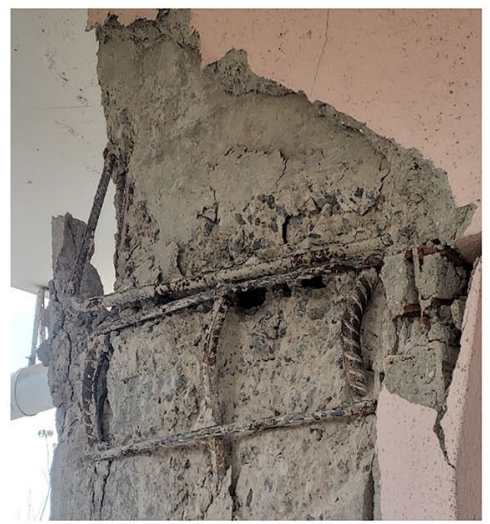

(f) $38.4672074628,27.1944161101$

Fig. 26 Beam-column joint damage 
lateral load loading, $X$-shaped shear cracks are frequently encountered in these columns. The shear cracks that occur completely compensate for the load-bearing capacities of these columns.

If such a structure is designed, the shear safety of this area should be increased by tightening the appropriate stirrups in the column free zone (wide spacings should not exceed $10 \mathrm{~cm}$ ). According to the earthquake regulations, the shear force to be used in the calculation is calculated using Eq. (2).

$$
V_{e}=\frac{M_{a}+M_{\approx}}{l_{n}} \leq\left\{\begin{array}{l}
V_{r} \\
0.85 A_{w} \sqrt{f_{c k}}
\end{array}\right.
$$

Here, the bottom moment and top moment of a short column were calculated as two moments $M_{a}=1.4 M_{r a}$ and $M_{\approx}=1.4 M_{r \approx}$, respectively. Parameter $M_{r}$ indicates the crosssectional strength moment, $l_{n}$ represents the length of the short column, $V_{r}$ indicates the shear strength of the column cross section, $A_{w}$ shows the body area of the column section and $f_{c k}$ shows concrete compressive strength. To prevent damage to short columns that are formed by building residents later, the following should be done:

(1) During construction, a suitable joint gap should be left between the columns and wall, and the gap should be filled with a material that can be tightened.

(2) To prevent free ends in the column, filling walls should be built on the sides of two columns, and the window space should be reduced. Figure 27 shows this kind of critical failure.

\subsection{Inadequate gaps between adjacent buildings}

Since the income of the city centres is higher, buildings are built without insufficient gaps being left between the buildings. Since the age of buildings is different, it is expected that adjacent buildings will collide during an earthquake. These collisions can cause significant damage and destruction to structures. This situation has become more dangerous, especially in buildings whose floor levels are not the same. In the 2018 earthquake regulations, the following restrictions were introduced because building blocks that are separated from each other by structural joints carry the risk of colliding and being damaged in an earthquake:

(1) For example, the prevention of torsional irregularity and a balanced arrangement of carrier system elements must be done. Except in cases where the building or building blocks are in planning for a long period of time, the separation of the carrier system into independent blocks by structural joints should be avoided as much as possible.

(2) The length of the building or building blocks in the plan, regardless of the earthquake calculation, for reinforced concrete members, using the effective section stiffness, can be determined according to the carrier system calculation to be made for temperature change and shrinkage effects.

In addition to this, according to TSC-2007 and TSC-2018, the minimum size of gaps should be $30 \mathrm{~mm}$ up to a height of $6 \mathrm{~m}$ and from there on, a minimum of $10 \mathrm{~mm}$ should be added for each $3 \mathrm{~m}$ height increment. These gaps can be filled with construction residue. For this reason, leaving more space than these values would be more appropriate in terms of 


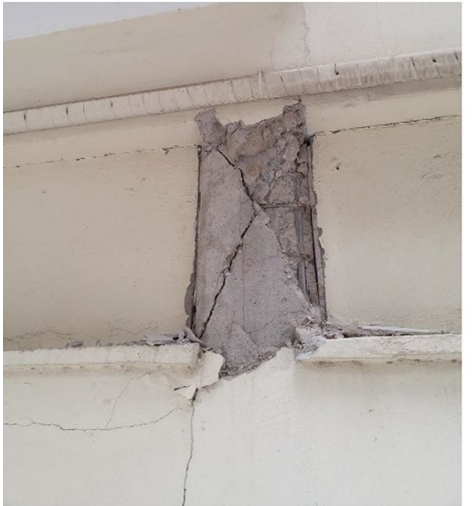

(a) $(38.4627013748,27.1080045686)$

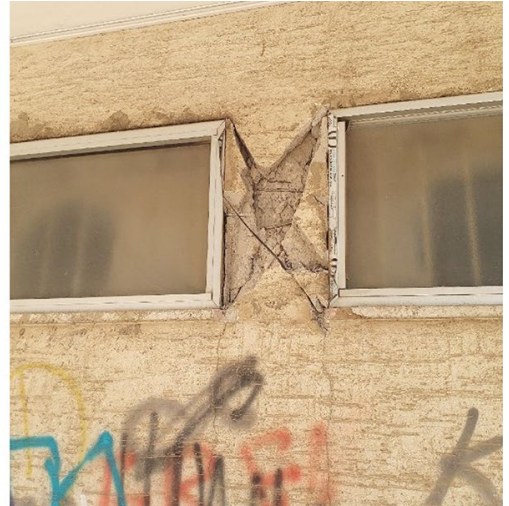

(b) $38.4624458534,27.1079189062$

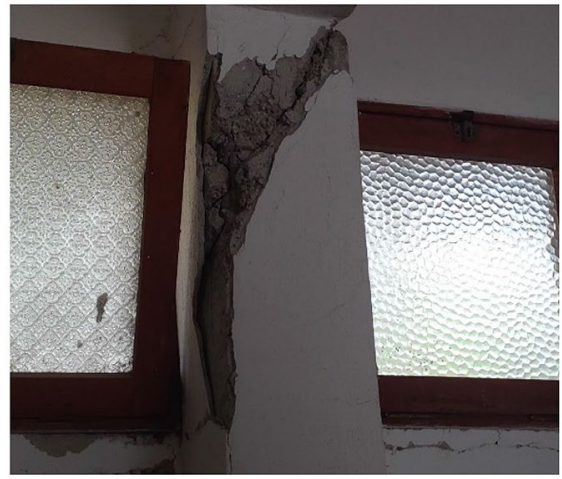

(c) $38.6852482656,26.7365814368$

Fig. 27 Short column damages

preventing the buildings from colliding. Unless a more unfavourable value is obtained in accordance with requirements defined in the previous statement, TSC-2007 requires that the size of the gaps should not be less than the sum of the absolute values of average story displacements multiplied by the coefficient $\alpha$. If the floor levels on all stories of adjacent buildings are the same, then $\alpha=\frac{R}{4}$; otherwise, $\alpha=\frac{R}{2}$. In these equations, the factor for the structural behaviour is R. However, according to TSC-2018, unless a more unfavourable value is obtained in accordance with requirements defined in previous statement, the size of gaps should not be less than the sum of the absolute values of average story displacements multiplied by the coefficient $\alpha$. If adjacent floor levels of buildings at all stories are the same, then the amount of the gap is $\alpha=0.25\left(\frac{R}{I}\right)$; if not, $\alpha=0.50\left(\frac{R}{I}\right)$. In these equations, the structural behaviour factor and building importance factor are indicated by $\mathrm{R}$ and $\mathrm{I}$, respectively. The buildings damaged because of the hammering effect are shown in Fig. 28.

\subsection{Strong beam-weak column}

In Turkey, especially in old reinforced concrete structures, the beam dimensions are larger than the column sizes to make the spaces and openings larger. A strong beam 


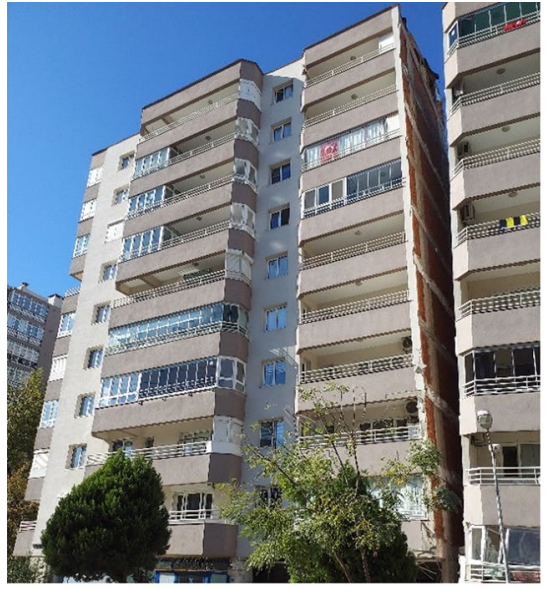

(a) $38.46219,27.18713$

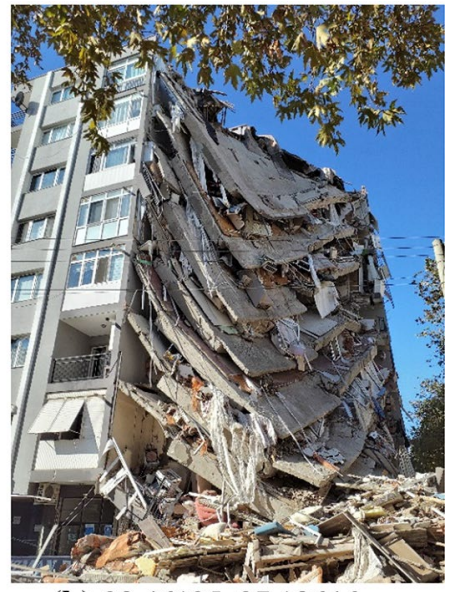

(b) $38.46135,27.18646$

Fig. 28 Damages to adjacent buildings during the September 30, 2020, Aegean Sea earthquake

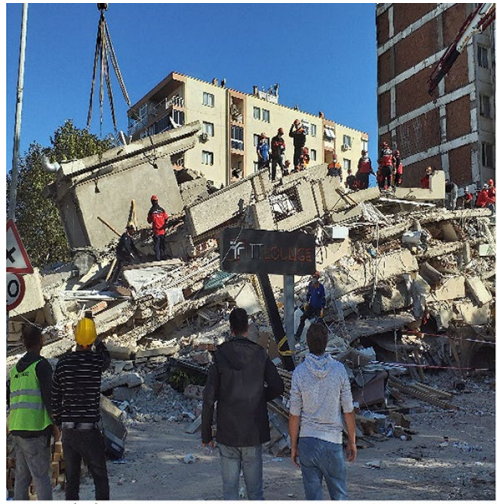

(a) $38.4586002103,27.1953536938$

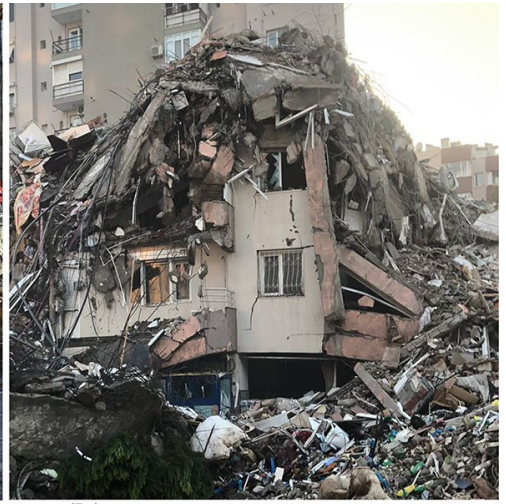

(b) $38.4686002103,27.1853536938$

Fig. 29 Total collapse due to strong beam-weak column

on a weak column means that the total bearing strength moment of the beams should not be higher than the columns. However, the 1997, 2007, and 2018 Turkish Seismic Codes require that the bearing strength moments of columns converging at a node point should be at least 1.2 times greater than the bearing moments of beams at that node. Weak columns in reinforced concrete structures of this design exhibit elastic behaviour at first and can withstand some horizontal load, but as the load increases, they cannot exhibit inelastic behaviour and collapse in a brittle manner. The main cause of the partial and total collapse during the İzmir earthquake was the presence of a strong beam-weak column combination. Figure 29 shows collapsed buildings where the column dimensions are considerably smaller according to the depth of the beams. Beams exhibit ductile behaviour since they are subjected to a much lower axial normal force than columns. Therefore, even if there is not a total collapse, shear fractures can occur in the columns without any damage to the beams (Fig. 30). To prevent such damage, the columns should be made stronger than the beams, and plastic joints should be 
Fig. 30 Failure of a due to strong beam-weak column effect during the İzmir earthquake

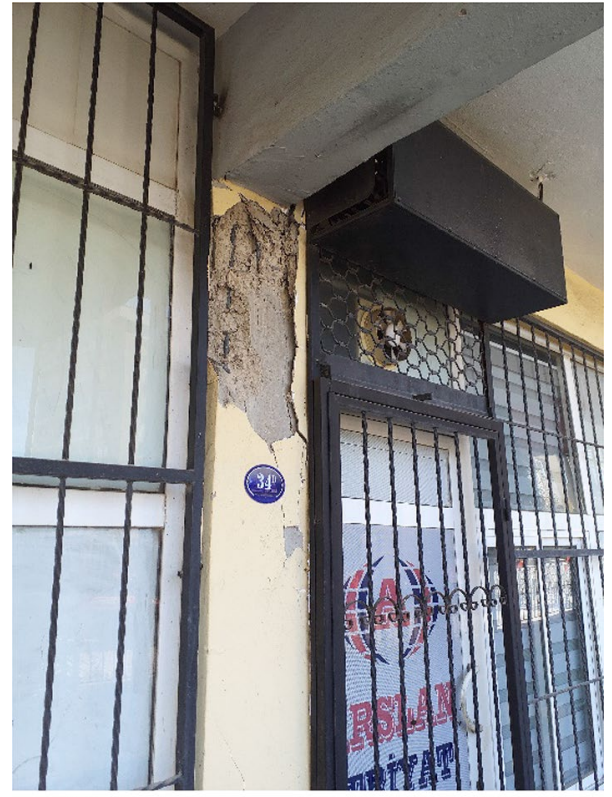

$38.4616919188,27.1805765036$

formed in the beams. Thus, brittle shear fractures will not occur at the column ends, and the total collapse of the structures will be prevented.

\subsection{Poor concrete quality and corrosion}

The concrete strength is one of the most important parameters affecting the earthquake performance of a reinforced concrete building. The use of ready-mixed concrete was not compulsory in Turkey until the 1999 Kocaeli earthquake, and handmade concrete was generally used without using a vibrator. After this earthquake, the use of readymixed concrete and the compressive strength of the concrete to be poured on-site were required to be at least $20 \mathrm{MPa}$. With the 2018 earthquake code, the lowest concrete compressive strength was increased to $25 \mathrm{MPa}$. However, in the 1975 Turkish Seismic code, there is a requirement that concrete with a concrete compressive strength of at least $18 \mathrm{MPa}$ should be used for buildings located in regions with a high earthquake risk. Moreover, the compressive strengths of the concrete cores in the observed collapsed and damaged structures ranged from approximately 6-11 MPa. Another reason why the buildings did not show the expected performance was a lack of ribbed reinforcement in the structural elements and the excessive corrosion that occurred in these reinforcements. The non-ribbed reinforcements prevented the concrete and reinforcement from having sufficient adherence. In addition, the use of aggregate in the concrete of the buildings that was extracted from the Aegean Sea and not washed caused corrosion in the reinforcements and adverse effects on the concrete. Figure 31 shows the poor quality of the concrete and the corroded reinforcement bars in various buildings. 


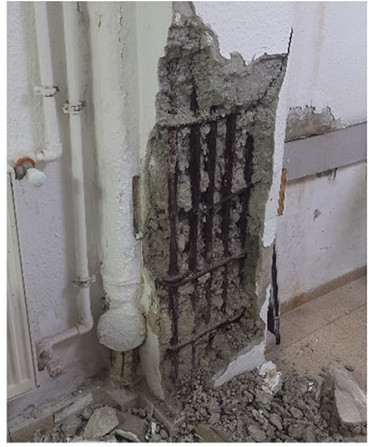

(a) $38.39207,27.08763$

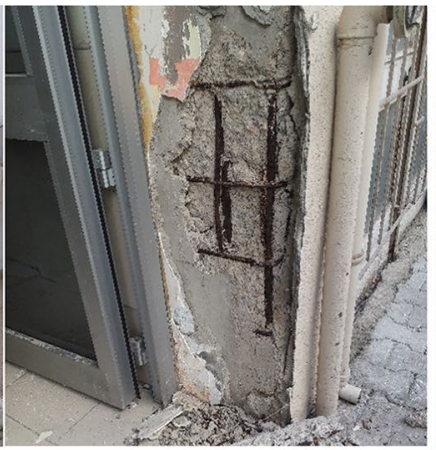

(b) $38.4246,27.13292$

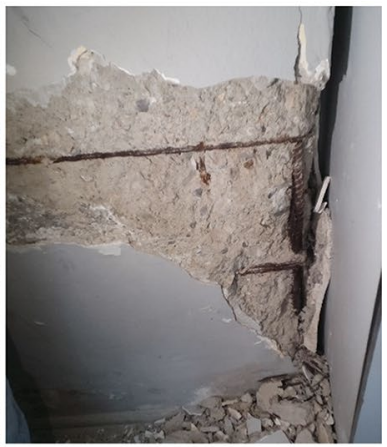

(c) $38.4618,27.20081$

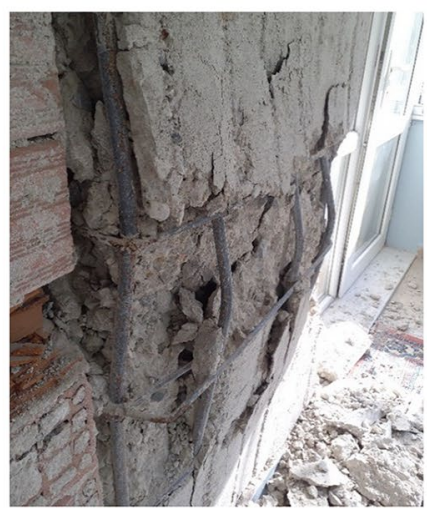

(d) $38.45680,27.18880$

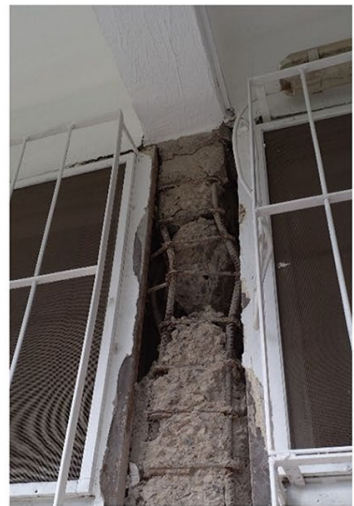

(e) $38.45298,27.17935$

Fig. 31 Failure of column due to poor concrete quality during the September 30, 2020, Aegean Sea earthquake

\subsection{Soft and weak story mechanism}

The ground floors of the buildings on the side of the street in the city centre are used as commercial spaces. Larger spaces are obtained by removing the infill walls on these floors. The contribution of partition walls to rigidity is often not considered when designing structures. These walls are only applied to the structure as a load. However, partition walls contribute significantly to the initial stiffness of structures. The absence of walls on the ground floor causes this floor to shift more than the neighbouring floors. Another factor that creates a soft floor is the high floor height on shop floors. The height of the columns causes the stiffness of the floor to decrease. During an earthquake, all the total displacement occurs on this floor, and very large second-order moments occur. Therefore, a building will collapse on top of this floor. The displacement of the ground floor should be limited to prevent soft floor damage. The stiffness of this floor should be increased by increasing the column dimensions and using reinforced concrete shear walls. Figure 32 shows total collapses that arose from soft story mechanisms in various reinforced concrete buildings during the Aegean Sea earthquake. 


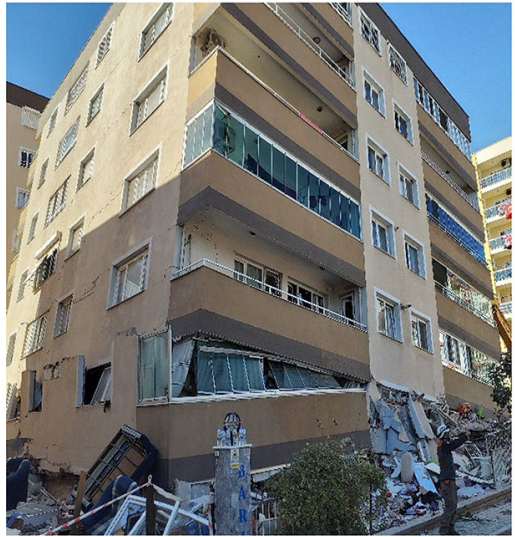

(a) $38.46603,27.16176$

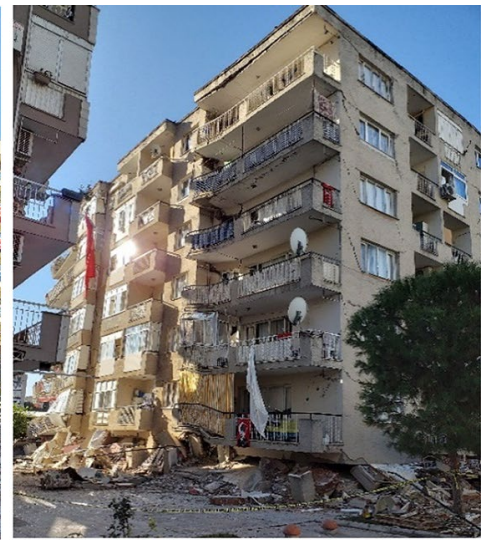

(b) $38.46319,27.18960$

Fig. 32 Soft-story mechanism

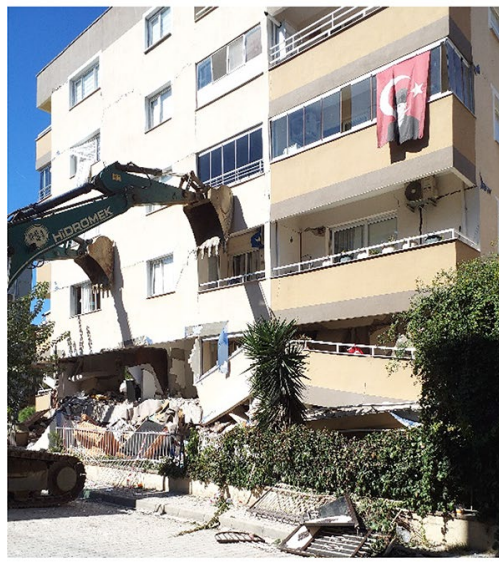

(a) $38.46052,27.18024$

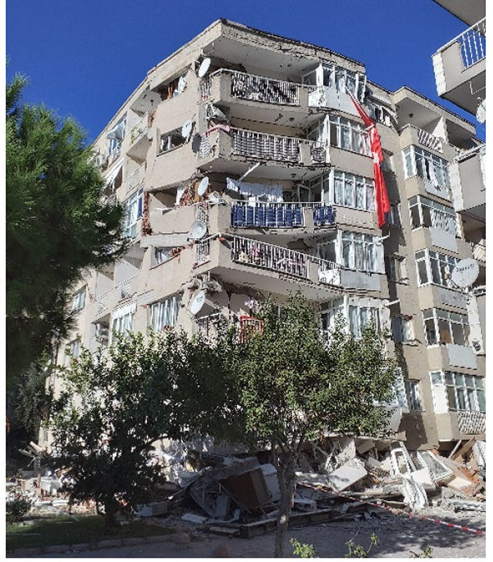

(b) $38.46319,27.18960$

Fig. 33 Soft-story mechanism

In old buildings in Turkey, the vertical main bearing element dimensions were reduced as the upper floors went up. Sometimes, curtain walls were built up to a certain floor and continued with columns instead of curtains on the other floors. Homeowners can sometimes create a large space by removing partition walls from the mezzanine floors. Such an approach is completely inconsistent with earthquake-resistant building design procedures. On floors with a reduced rigidity, excessive displacement demand occurs because of earthquakes, and collapses may occur on these floors. To prevent this type of failure mechanism, TSC 2007 and 2018 require that, in RC buildings, in each of the orthogonal earthquake directions, the ratio of the effective shear area of any story to the effective shear area of the story immediately above should not be less than 0.80 . Figure 33 illustrates buildings that collapsed due to the weak-story mechanism. 


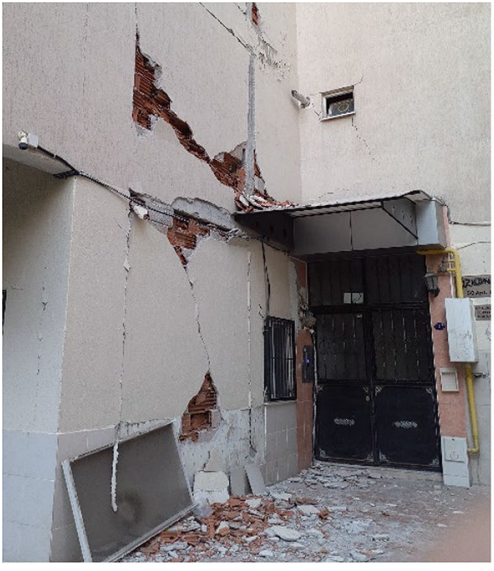

(a) $38.4541912329,27.1901375828$

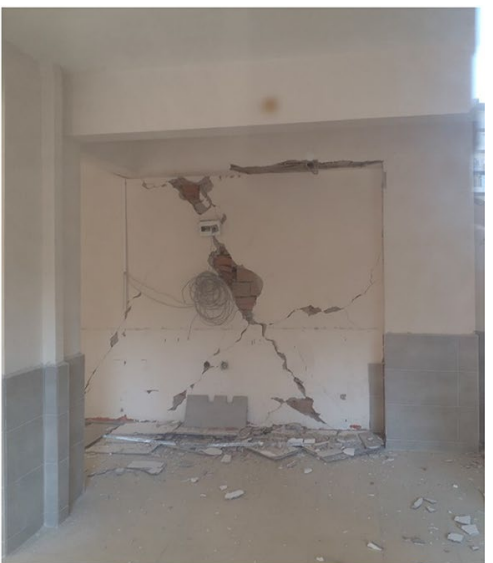

(b) $38.4551863678,27.1801988328$

Fig. 34 Shear cracks on walls without openings

\subsection{Damage to infill walls}

The main purpose of infill walls in reinforced concrete structures is to separate spaces. As a result, during the design process, the walls are usually only affected by the vertical load of the structure. However, this approach is not completely accurate for walls. Infill walls affect the structural response in many ways, particularly the lateral rigidity, under cyclic loads, such as during earthquakes. One of the most important effects of infill walls is that they increase the horizontal load carrying capacity of a structure. However, it must be stated that the contribution of infill walls to the rigidity of a structure is suddenly reduced when they become cracked or damaged (Yön et al. 2017; Onat et al. 2018; Braga et al. 2011; Onat 2019; Doğangün 2021; Onat and Panto 2021).

Damage to the infill walls can be classified as follows:

- In-plane shear damage (with and without opening).

- Out-of-plane overturning damage (partial or collapse).

- Damage to the corners of perpendicular walls.

- Damage to the walls that stand on cantilevers.

Walls without openings are generally supported by columns or shear walls on their two vertical edges. Because the mass of a building is summed at the floor level, horizontal seismic forces can be expected to act at the floor level. Under these loads, shear cracks are enhanced on the infill wall plane. The spread of cracks on the wall plane is affected by the height/length ratio of the wall. Figure 34 depicts the traditional crack shape of an " $X$ ".

In the corners of exterior walls where there are window spaces, in-plane cracks in the form of steps occur in the plaster lines within the plane of the wall due to shear force. To prevent these cracks, the windows should be kept away from the wall joints, and the wall should be prevented from supporting the wall in this area. Figure 35 shows this type of damage.

Out-of-plane damage is a common type of damage to filled walls. Upon the growth of in-plane cracking in walls, the connection of the walls to the structural frameworks 


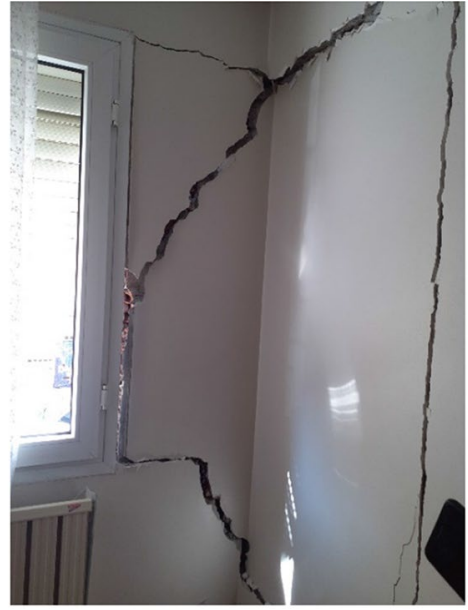

(a) $38.4674770856,27.1608656809$

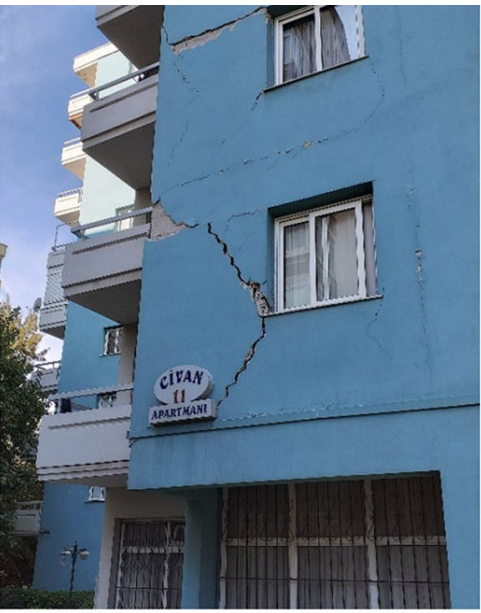

(b) $38.4644893459,27.1903477899$

Fig. 35 Shear cracks on corner walls with openings

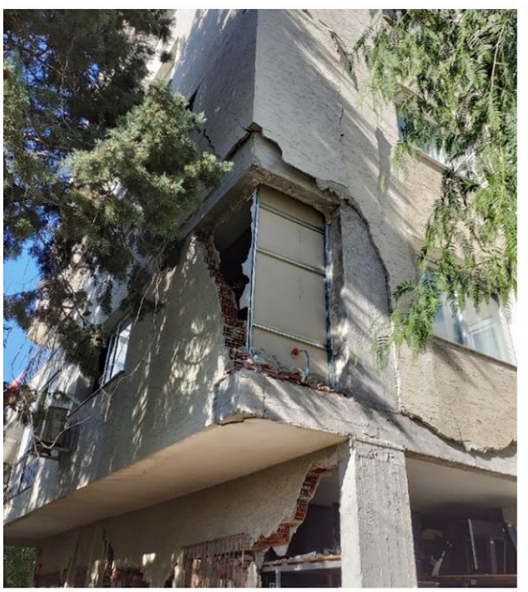

(a) $38.4539375029,27.1902007979$

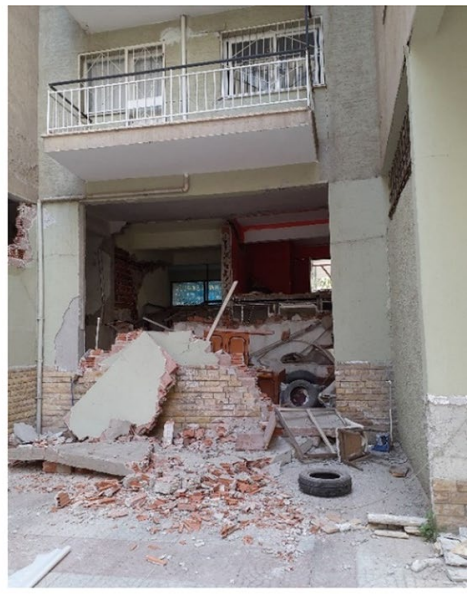

(b) $38.4539172313,27.1809149666$

Fig. 36 Out-of-plane mechanism of infill walls

weakens. Thus, since there is no element to support the wall, it is knocked out of the plane of the wall. This type of damage is seen in Fig. 36.

Because the earthquake force acts both on the plane of the wall and outside of it, both in-plane and out-of-plane damage can occur on the wall at the same time. The main reason for these types of damage is that the wall does not have sufficient rigidity in its plane and is not rigidly attached to a frame member. Figure 37 shows this kind of failure mechanism.

Furthermore, as shown in Fig. 38, heavy in-plane shear damage was observed in new residences. The reason for this damage was the lack of rigid body diaphragm motion of the structural system due to a big opening in the centre of the slab. 


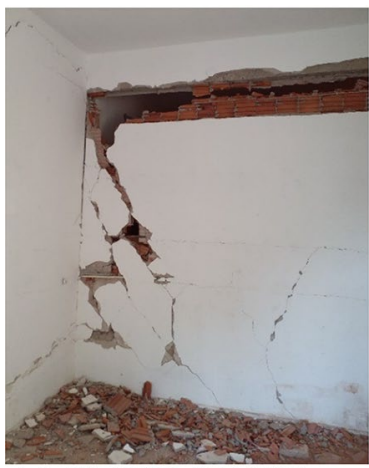

(a) $(38.46327,27.18983)$

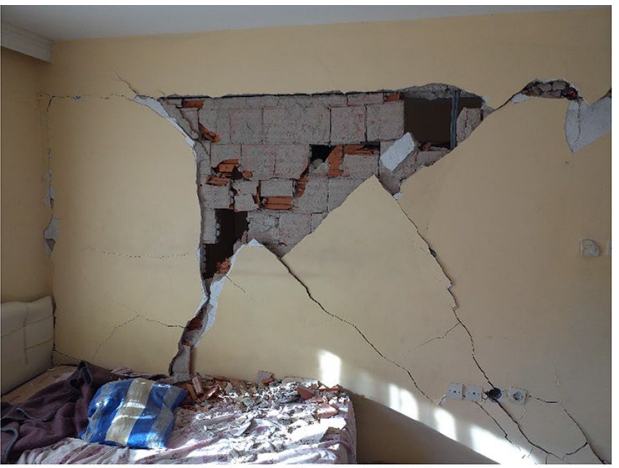

(b) $(38.451198,27.18373)$

Fig. 37 Combined mechanism of infill walls

Fig. 38 In-plane infill damage of new residence

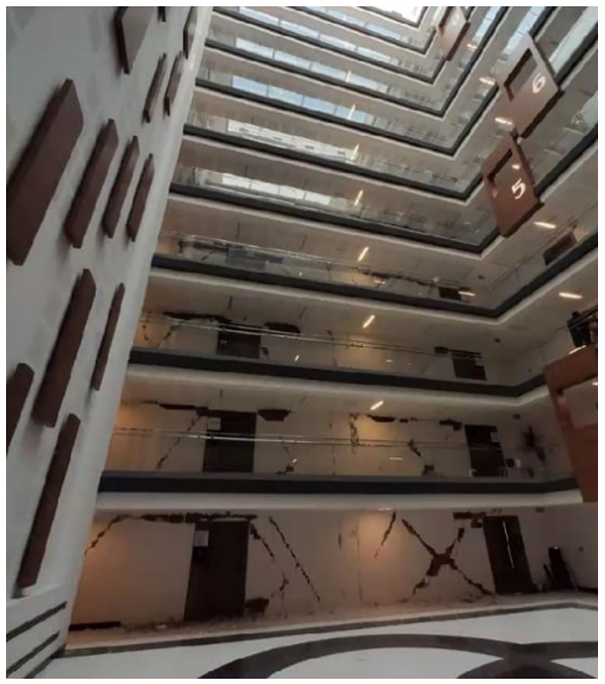

Figure 38 depicts a public residence with a large central gap. Despite the lack of substantial cracks in the core shear wall, the infill walls showed extensive shear cracks. Damage to the infill walls in a modern house caused by ground motion during an earthquake that is less intense than the design specifications is unexpected. It is presumed that the encircling shear walls were unable to control the inter-story drifts since the structural system lacked a rigid diaphragm contribution. Another theory is that software modelling mistakes were responsible for this unusual type of damage due to incorrect assumptions. Slab motion is believed to be rigid diaphragm motion during the modelling process. Unexpected behaviour can be seen in the absence of rigid motion. Furthermore, the infill walls surrounding the residence doors were severely damaged because of the poor detail design and exhibited unforeseen drift. Due to the severity of this damage, it is imperative that slab discontinuity be considered and appropriate load transfer methods to shear walls be proposed. This is a new type of damage observed during earthquakes in Turkey in the last decade, and there is a consensus among scientists on this finding. 


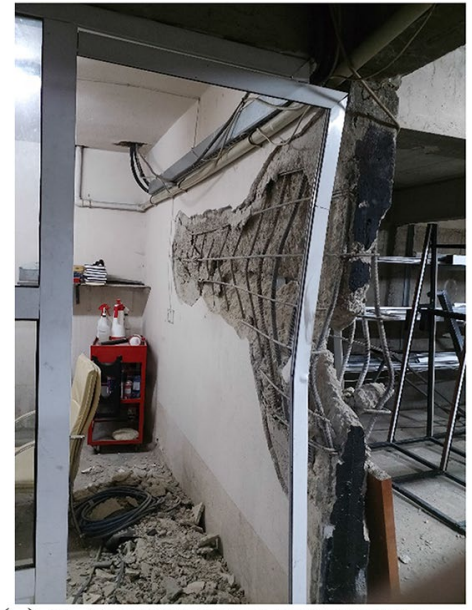

(a) $38.4511986002,27.1837323904$

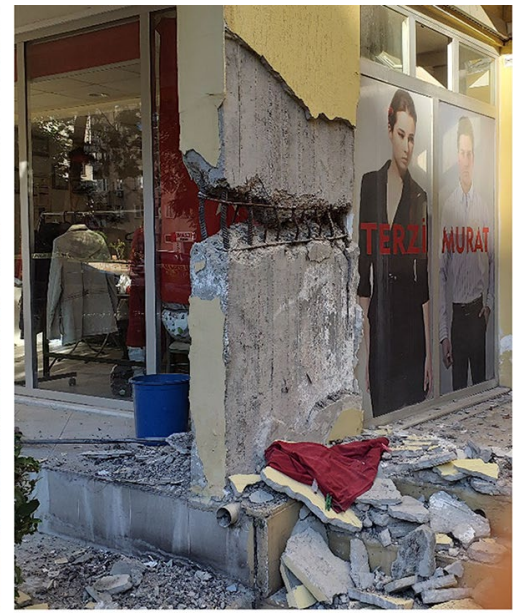

(b) $38.4583019854,27.1914235063$

Fig. 39 Reinforced concrete shear wall damages

\subsection{Shear wall damage}

Reinforced concrete shear walls are important load-bearing elements used to limit floor drifts, provide rigidity to the structure and increase the structural performance of buildings against horizontal shear forces. If these walls, which are subjected to high shear forces during the earthquake, are not designed at the appropriate dimensions, the wall end zones are not formed, and if they are not placed in the appropriate places in the plan, the curtains fail to function and are significantly damaged. Figure 39 shows reinforced concrete shear wall damage during the Aegean Sea earthquake.

\section{Performance of masonry dwellings}

\subsection{Damage at the wall corners}

Damage at wall corners is caused by an out-of-plane vibration of the walls and commonly occurs due to a lack of connection between orthogonal walls. Vertical cracks and separations of adjacent walls are signs of corner damage. Figure 40 shows vertical cracks caused because of stress concentrations at the building corners, poor connections between the walls and the absence of bond beams. Vertical confining elements are recommended for confined masonry buildings to prevent this type of failure. According to TBEC-2018, the unsupported plan length between load-bearing walls should be no less than $5.5 \mathrm{~m}$ in Seismic Design Classes 1 and 2, and $7.5 \mathrm{~m}$ in Seismic Design Class. If this condition is not satisfied, reinforced concrete vertical bond beams should be built on walls with an axis-to-axis spacing of no more than $4.0 \mathrm{~m}$ in the plan. However, the unsupported length of such walls should not be more than $16 \mathrm{~m}$. 


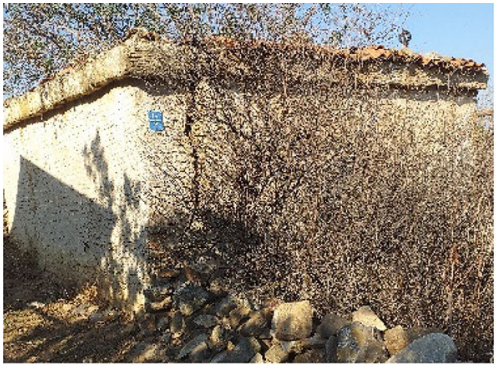

(a) $38.1092405181,27.6159247796$

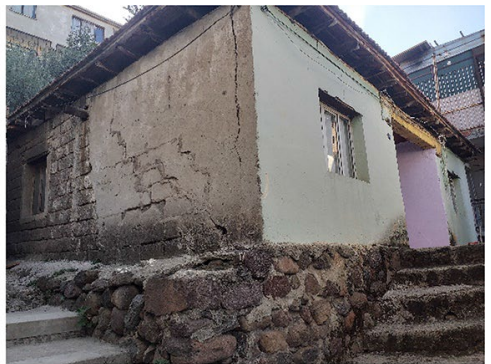

(b) $38.4609025153,27.1861105385$

Fig. 40 Damages at the wall corners

\subsection{Out-of-plane failure mechanism}

In masonry buildings, failure was caused by insufficient details connecting walls to the roof and walls to each other as well as a lack of bond beams. When masonry buildings are subjected to earthquake effects in the perpendicular direction to the wall plane, outof-plane mechanisms occur as an overturn of the whole wall or a sizeable portion of it due to the absence vertical bond beams, which contributes to the earthquake resistance of the wall. Fig. 41 shows the out-of-plane mechanism for walls. Different materials were used in the inspected construction, such as briquet, brick, and stone masonry walls in different buildings. Generally, brick and briquet walls were damaged due to unsupported corners with girders (Fig. 41e, f). However, when materials with different properties are used together in a wall or building (Fig. 41c), uncertainties in the rigidity and strength appear and consequently cause problems in the load sharing, especially during earthquakes. For instance, in a building with one edge made of a thick stone wall and the other edge made of thin or unsupported walls, additional torsional moments can come into being because of the rigidity irregularity in the plan.

The workmanship for the walls was not properly been conducted. Clay mortar was employed instead of cement mortar among the stones as a binder due to economic reasons. The binding of clay mortar is weak and becomes weakened over time depending on the weather conditions. Since thickness of the wall was relatively large, the walls were constructed by using more than one stone along the thickness direction. The outer layer of the thick stone walls was built with large coarse stones with a relatively smooth surface. However, smaller rubble stones were used between the two outer layers and did not provide connections among them. This situation caused the inner and the outer layers of the wall to behave independently by weakening the connections along the wall thickness direction.

\subsection{In-plane failure mechanism}

Shear diagonal damage commonly occurs at the edge of window and door openings, in the planes of walls where the shear strength is low and at corners that do not have horizontal and vertical bond beams. Inappropriate openings or their locations in load-bearing walls enhance shear stresses under seismic loads. Thus, the stiffness of the wall decreases, and diagonal cracks occur at the edges of openings. TBEC-2018 requires the use of vertical and 


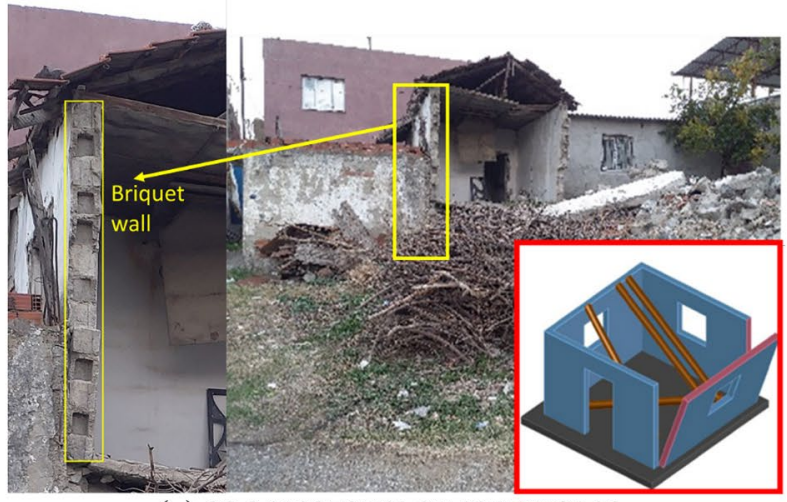

(a) $38.3410278761,27.1375578144$
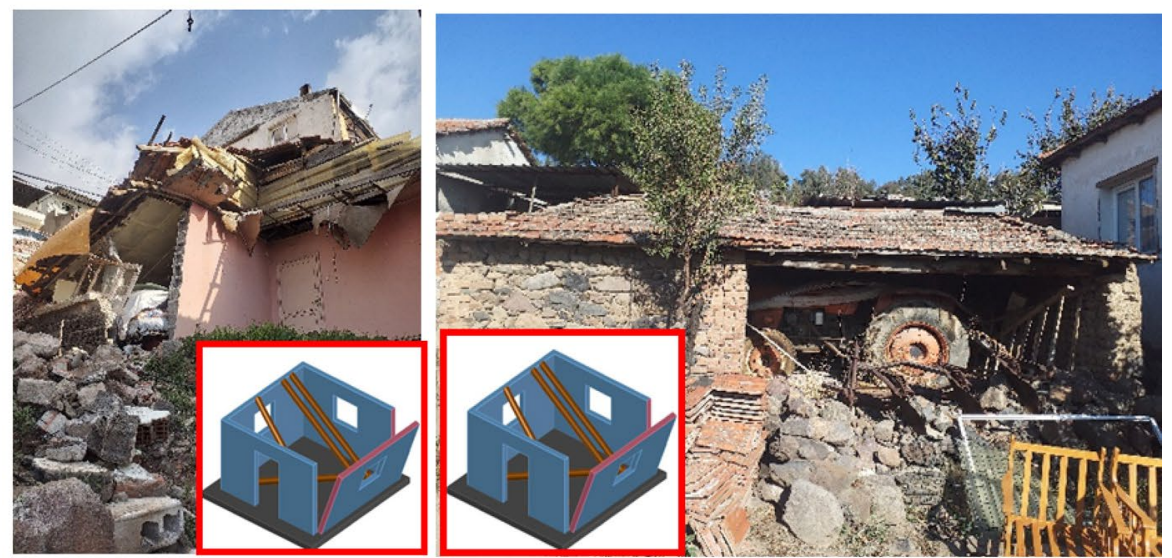

(b) $38.4981330038,27.0768424058$ (c) $38.4981330038,27.0768424058$

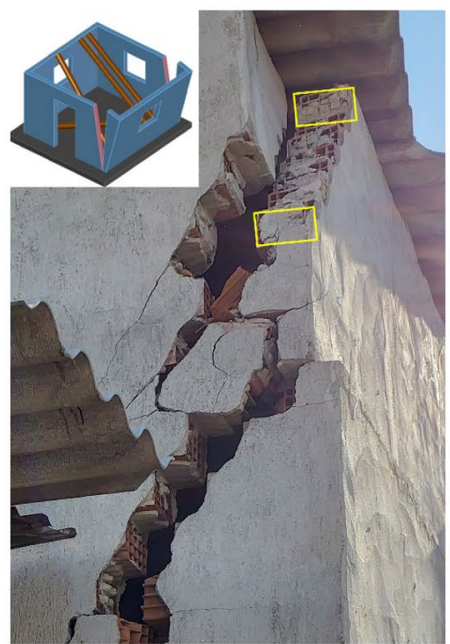

(d) Out-of-plane collapse of brick wall

Fig. 41 Out-of-plane failure mechanism (Small figures were adopted from Altunışık et al. 2021) 


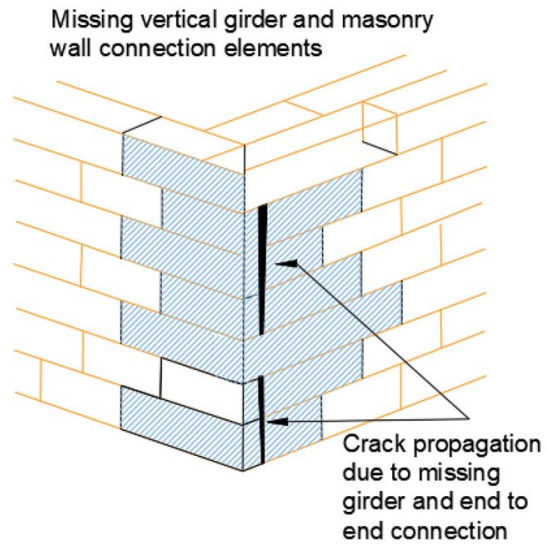

(e) Crack propagation

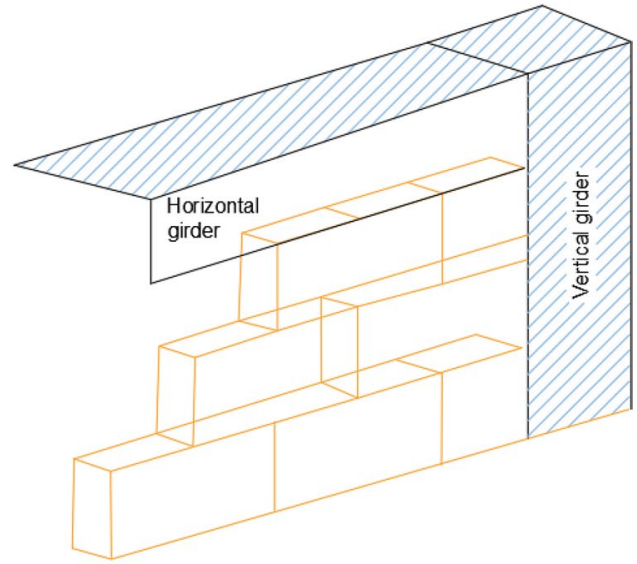

(f) Correct technique

Fig. 41 (continued)

horizontal bond beams to avoid this type of damage. Fig. 42 shows diagonal shear cracks in masonry buildings in the earthquake region.

\section{Tsunami damage assessment}

Tsunamis leave various traces in the areas they affect. These traces may disappear in a short time due to natural causes or human activity. The tsunami triggered by the October 30, 2020, Samos earthquake was not recorded by a wave gauge. So, the wavelength was measured on the site manually. The tsunami effect investigations on the Turkish coast were concentrated in three main regions by the authorities (METU 2020):

(i) Alaçatı and Zeytineli regions in the northwest.

(ii) Sığacık Bay and Akarca region on the coast of Seferihisar in the north.

(iii) Tepecik and Gümüldür regions in the northeast.

Within approximately 10 and 20 min, the first wave of the tsunami struck the coasts of Samos and Izmir, respectively. The city of Vathi was the most settled region on Samos Island, but the maximum flow depth was quite shallow $(20 \mathrm{~cm})$, and only minor floods were reported in commercial and residential structures along the beach, as illustrated in Fig. 43. (Manos 2020; Altunışık et al. 2021).

The highest tsunami height measured in Siğacık Bay was obtained on the coast of the Kaleiçi region and was $2.31 \mathrm{~m}$. At Akarca, the highest wave (climbing) height was measured to be $3.82 \mathrm{~m}$ at $91 \mathrm{~m}$ inland from the shore. Water splash marks $1.9 \mathrm{~m}$ above the ground were found on the wall of a heavily damaged dwelling near the shore $(0.89 \mathrm{~m}$ elevation). It was observed that the tsunami effect decreased as it progressed along the coast in the southeast direction from the Akarca region. Beyond the Gümüldür region, no tsunami dominant effect was observed. The effect of the tsunami decreased toward the south from the V-shaped cape between Tepecik and Gümüldür. The depth of the flow on land in the northern Zeytineli region was determined to be $1.9 \mathrm{~m}$ from traces on the trunks of 


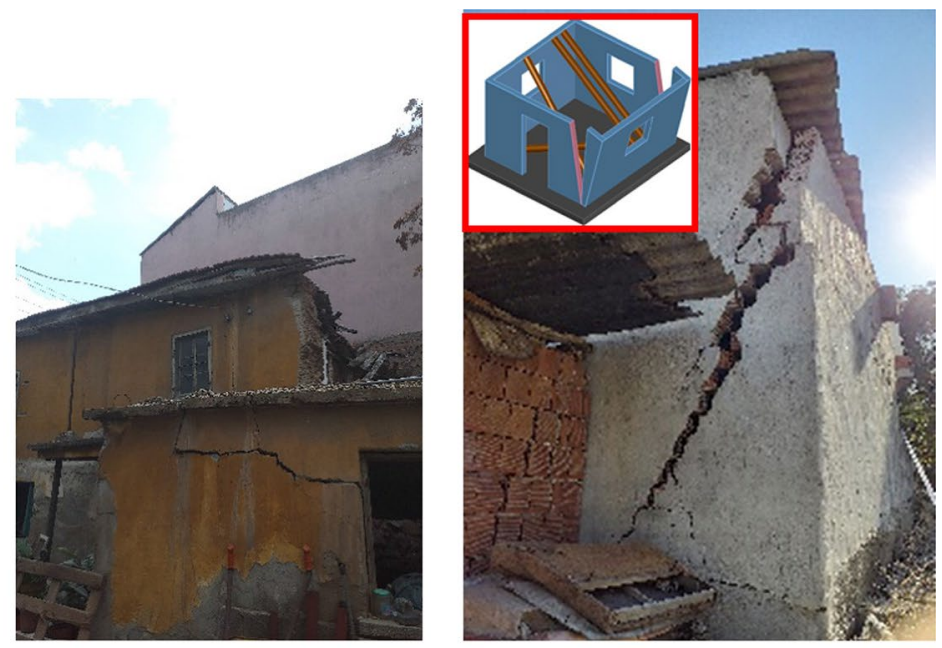

$\begin{array}{lll}\text { (a) } 38.4234159808,27.2314568318 & \text { (b) } 38.3539732504,27.1497469153\end{array}$

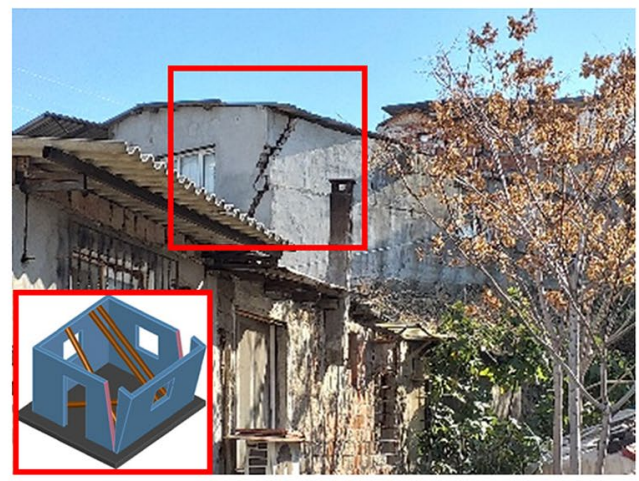

(c) $38.3234159808,27.223577235$

Fig. 42 Shear cracks at masonry building (Small figures were adopted from Altunışık et al. 2021)

Fig. 43 The view of Vathi after the tsunami (Altunışık et al. 2021)

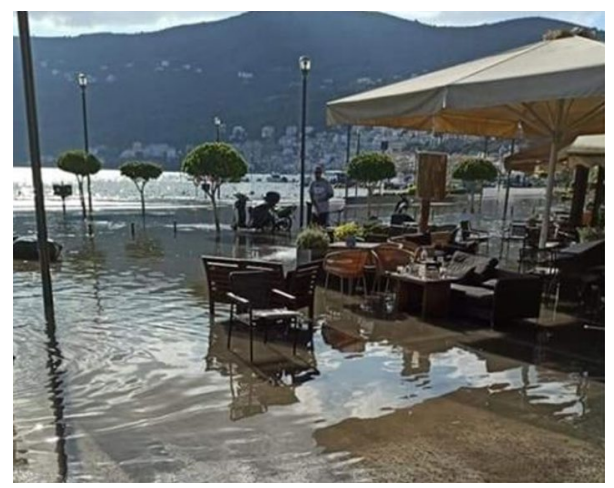


Fig. 44 Tsunami maximum inundation and flow depth simulation on coast of Izmir (METU 2020)

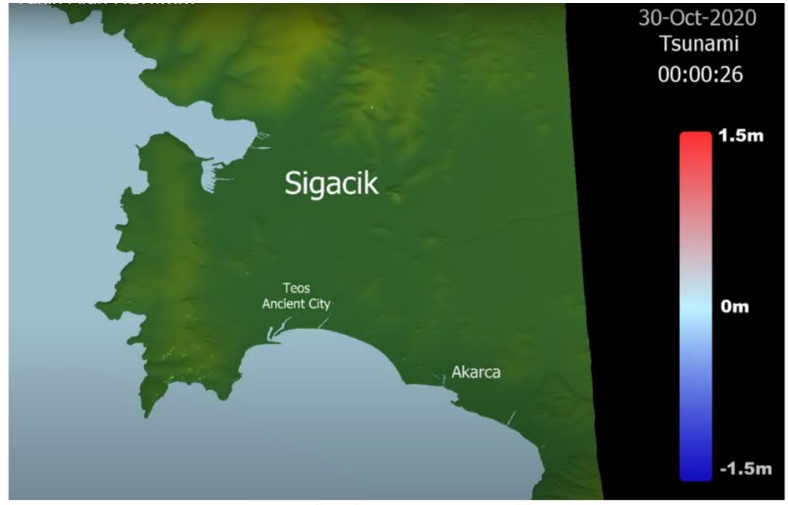

(a) Before tsunami

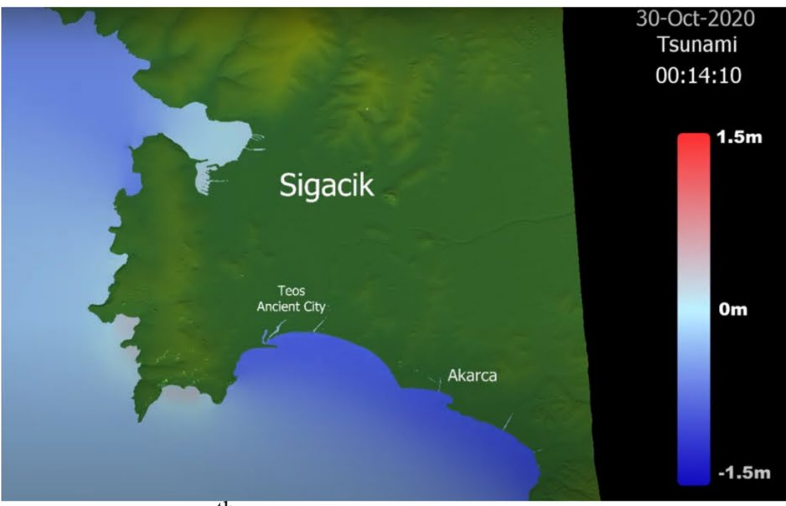

(b) $14^{\text {th }}$ seconds after tsunami starts

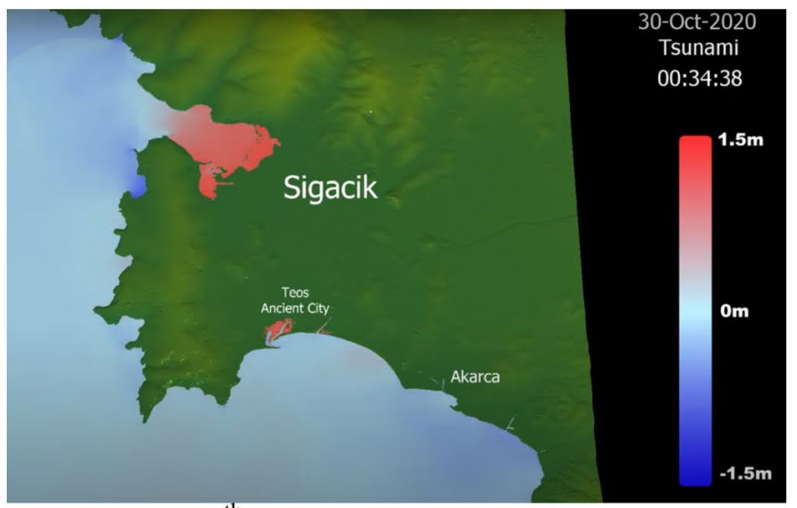

(c) $34^{\text {th }}$ second after tsunami starts

palm trees $50 \mathrm{~m}$ from the coast. At Kusadasi Davutlar Sevgi Beach, traces of the tsunami were found at the shelter for fisherman and at the canal entrance here. It was observed that the water level rose $\sim \mathrm{m}$ in this region (METU 2020). Figure 44 depicts the tsunami and maximum wave height simulation. 


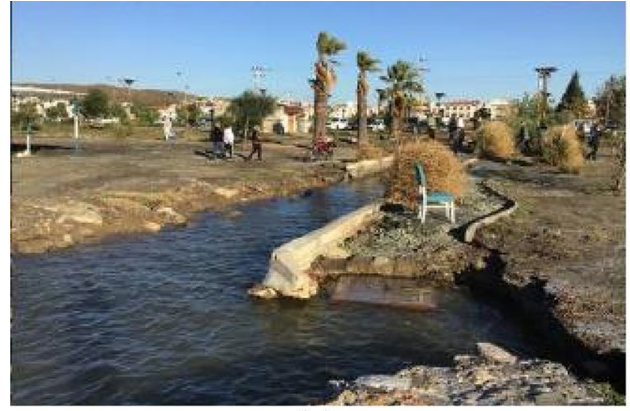

(a)

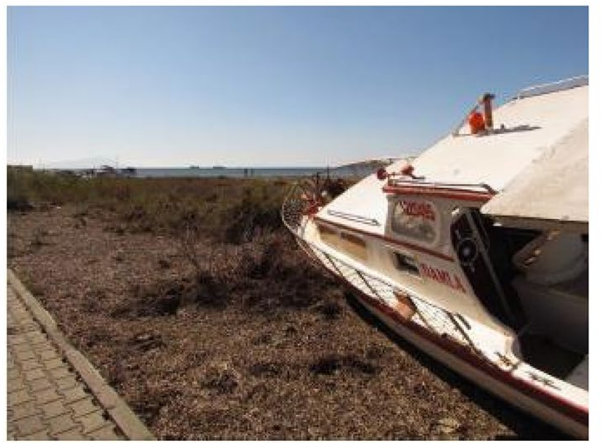

(c)

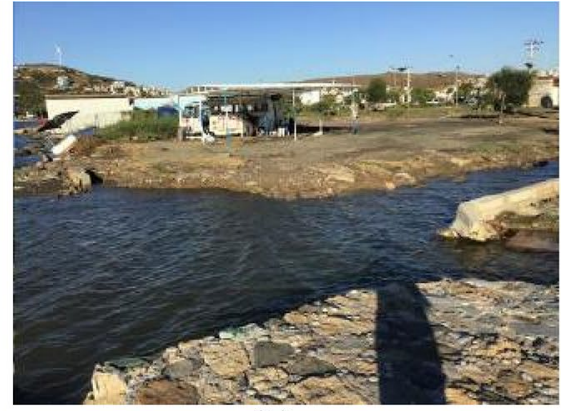

(b)

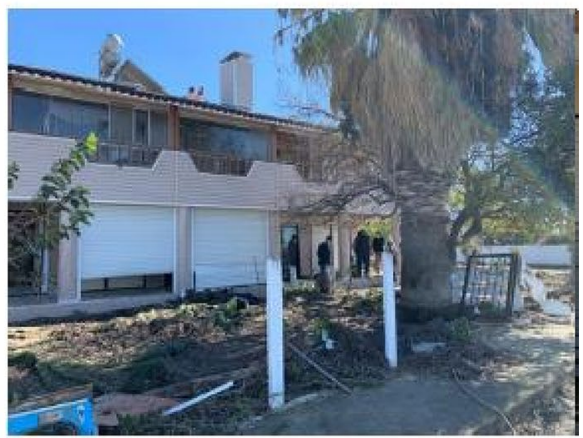

(d)

Fig. $45 \mathbf{a}, \mathbf{b}$ and $\mathbf{c}$ maximum inundation distance $\mathbf{d}$ maximum flow depth (METU 2020)

After the tsunami, the effect of it on the coast of Izmir and the structural system is presented in Fig. 45.

\section{Conclusions and recommendations}

A strong earthquake hits the Aegean Sea near Samos Island on October 30, 2020. Many structures collapsed or were severely damaged. According to a current field investigation, 13 buildings completely collapsed and 110 were severely damaged after October 30, 2020, in Samos after the Aegean Sea earthquake. Buildings that collapsed or were in danger of collapsing were found $60 \mathrm{kms}$ away from the epicentre. The heavily damaged buildings were built prior to the year and had 7 or 10 stories. According to inspections performed on the damaged systems, different contractors paid different amounts of attention to their structural systems. In addition, the influence of a younger geological unit was characterized by a low rigidity. Sedimentary deposits were a key contributor to the severity of the shaking. The amount of intensity depended on the soil amplification from the 0.5 to $1.5 \mathrm{~s}$ period range increased due to the basin effect on the structural systems by $40 \%$. According to field observations and structural assessments, the following recommendations were developed to avoid repeating mistakes during the construction process and eliminate unforeseen conditions, such as the basin effect. 


\subsection{For structural systems}

- Incorrect system selection.

- Incorrect seismic design.

- Interrupted main bearing elements and discontinuous frames.

- Large gaps on slabs.

\subsection{For available RC structural systems}

- Insufficient shear wall.

- Existing of short colum.

- Low concrete quality.

- Using of unribbed reinforcement.

- Insufficient angle of transverse reinforcement.

- Insufficient space length between the shear reinforcement.

- Insufficient beam-column joint.

- Insufficient detailing of shear walls.

- Corrosion of rebar.

\subsection{For available masonry dwellings}

- Lack of horizontal or vertical bond beams.

- Large unsupported wall lengths.

- Lack of connection detail.

- Low quality of bonding material.

As a result, in Turkey, which is located on the most active faults of the world, the buildings that are not earthquake resistant and do not comply with the regulations need to be renewed or the strengthening applications are urgently required. The October 30, 2020, Aegean Sea earthquake showed that a tsunami could impact settlements close to the coast of Turkey. For this reason, tsunami-related warning centres should be established, coastal areas that may be exposed to the tsunami effect should be determined and settlement plans should be made accordingly.

\section{Declarations}

Conflict of interest The authors have no conflicts of interest to declare that are relevant to the content of this article.

\section{References}

AFAD (2020) İzmir Earthquake Report, (In Turkish)

Akinci A, Cheloni D, Dindar AA (2021) The 30 October 2020, M7.0 Samos Island (Eastern Aegean Sea) Earthquake: effects of source rupture, path and local-site conditions on the observed and simulated ground motions. Bull Earthq Eng. https://doi.org/10.1007/s10518-021-01146-5

Akkar S, Sandıkkaya MA, Bommer JJ (2014) Empirical ground-motion models for point-and extendedsource crustal earthquake scenarios in Europe and the Middle East. Bull Earthq Eng 12(1):359-387 
Altunışık A, Atmaca B, Kartal ME, Günaydın M, Demir S, Uluşan A (2021) Assessment of structural damage following the October 30, 2020 Aegean Sea Earthquake and Tsunami. J Earthq Tsunami. https:// doi.org/10.1142/S1793431121500299

Ammon CJ, Ji C, Thio HK, Robinson D, Ni S, Hjorleifsdottir V et al (2005) Rupture process of the 2004 Sumatra-Andaman earthquake. Science 308(5725):1133-1139. https://doi.org/10.1126/science.11122 60

Aras F, Düzci E (2018) Seismic performance of traditional stone masonry dwellings under Çanakkale seismic sequences. J Perform Constr Facil 32(4):04018029. https://doi.org/10.1061/(ASCE)CF.1943-5509. 0001173

Braga F, Manfredi V, Masi A, Salvatori A, Vona M (2011) Performance of non-structural elements in RC buildings during the L'Aquila, 2009 earthquake. Bull Earthq Eng 9(1):307-324. https://doi.org/10. 1007/s10518-010-9205-7

Calayır Y, Sayın E, Yön B (2012) Performance of structures in the rural area during the March 8, 2010 Elazı̆̆-Kovancilar earthquake. Nat Hazards 61(2):703-717. https://doi.org/10.1007/ s11069-011-0056-6

Demir S, Günaydin M, Atmaca B, Altunişik AC, Hüsem M, Adanur S et al (2021) Performance evaluation of reinforced concrete buildings during the Sivrice-Elazı $\breve{g}$ earthquake (M w= 6.8, January 24, 2020) in accordance with Turkish earthquake code. J Earthq Tsunami. https://doi.org/10.1142/S179343112 1500184

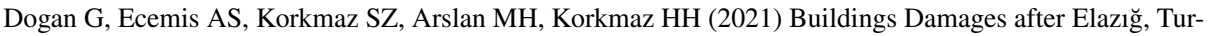
key Earthquake on January 24, 2020. Nat Hazards. https://doi.org/10.1007/s11069-021-04831-5

Doğangün A (2004) Performance of reinforced concrete buildings during the May 1, 2003 Bingöl Earthquake in Turkey. Eng Struct 26:841-856. https://doi.org/10.1016/j.engstruct.2004.02.005

Doğangün A, Yön B, Onat O, Öncü ME, Sağıroğlu S (2021) Seismicity of east Anatolian of Turkey and failures of infill walls induced by major earthquakes. J Earthq Tsunami. https://doi.org/10.1142/S1793 431121500172

Dogru A, Gorgun E, Ozener H, Aktug B (2014) Geodetic and seismological investigation of crustal deformation near Izmir (Western Anatolia). J Asian Earth Sci 82:21-31. https://doi.org/10.1016/j.jseaes. 2013.12.008

Durand V, Bouchon M, Floyd MA, Theodulidis N, Marsan D, Karabulut H, Schmittbuhl J (2014) Observation of the spread of slow deformation in Greece following the breakup of the slab. Geophys Res Lett 41(20):7129-7134. https://doi.org/10.1002/2014GL061408

Erken A, Nomaler GŞ, Gündüz Z (2018) The development of attenuation relationship for Northwest Anatolia region. Arab J Geosci 11(2):21

Fernandez M, Molina E, Havskov J, Atakan K (2000) Tsunamis and tsunami hazards in Central America. Nat Hazards 22(2):91-116. https://doi.org/10.1023/A:1008102600622

Geist E, Titov V, Synolakis C (2006) Tsunami: WAVE of CHANGE. Scientific American 294(1) 56-63. Retrieved June 16, 2021, from http://www.jstor.org/stable/26061300

Göçer C (2020a) Field Investigation of the performance of unreinforced masonry building structures during the June 12, 2017, Lesvos earthquake in the Aegean Sea. J Perform Constr Facil 34(5):04020095. https://doi.org/10.1061/(ASCE)CF.1943-5509.0001497

Göçer C (2020b) Structural evaluation of masonry building damages during the April 24, 2014 Gökçeada earthquake in the Aegean Sea. Bull Earthq Eng 18(7):3459-3483. https://doi.org/10.1007/ s10518-020-00833-Z

Günaydin M, Atmaca B, Demir S, Altunişik AC, Hüsem M, Adanur S et al (2021) Seismic damage assess-

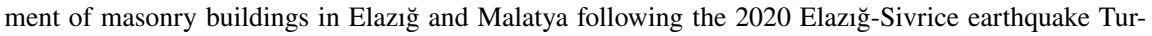
key. Bull Earthq Eng. https://doi.org/10.1007/s10518-021-01073-5

Gusiakov VK (2009) Tsunami history: recorded. In: Bernard EN, Robinson AR (eds) The sea. Harward University Press, Cambridge, pp 23-53

Handayani PM, Puspasari P (2020) Learning From Palu: Rebuilding A Better City in The Aftermath of Natural Disaster. Jurnal Pertahanan: Media Informasi ttg Kajian \& Strategi Pertahanan yang Mengedepankan Identity, Nasionalism \& Integrity 6(3): 442-457. https://doi.org/10.33172/jp.v6i3.907

Heidarzadeh M, Pirooz MD, Zaker NH, Yalciner AC (2009) Preliminary estimation of the tsunami hazards associated with the Makran subduction zone at the northwestern Indian Ocean. Nat Hazards 48(2):229-243. https://doi.org/10.1007/s11069-008-9259-x

Inel M, Ozmen HB, Akyol E (2013) Observations on the building damages after 19 May 2011 Simav (Turkey) earthquake. Bull Earthq Eng 11(1):255-283. https://doi.org/10.1007/s10518-012-9414-3

Kandilli Observatory and Earthquake Research Institute (KOERI), Boğaziçi University (2020) October 30, Aegean sea, Seferihisar (Izmir) offshore $(17.26 \mathrm{~km}) \mathrm{Mw} 6.6$ earthquake preliminary evaluation report. Press Bulletin, Istanbul, Turkey 
Keskin E, Bozdoğan KB (2018) 2007 ve 2018 Deprem Yönetmeliklerinin Kirklareli ili Özelinde Değerlendirilmesi. Kırklareli Üniversitesi Mühendislik Ve Fen Bilimleri Dergisi 4(1):74-90

Kiratzi A (2018) The 12 June 2017 Mw 6.3 Lesvos Island (Aegean Sea) earthquake: Slip model and directivity estimated with finite-fault inversion. Tectonophysics 724:1-10. https://doi.org/10.1016/j. tecto.2018.01.003

Krausmann E, Cruz AM (2013) Impact of the 11 March 2011, great east Japan earthquake and tsunami on the chemical industry. Nat Hazards 67(2):811-828. https://doi.org/10.1007/s11069-013-0607-0

Lay T, Kanamori H, Ammon CJ, Nettles M, Ward SN et al (2005) The great Sumatra-Andaman earthquake of 26 december 2004. Science 308(5725):1127-1133. https://doi.org/10.1126/science.11122 50

Liu Y, Santos A, Wang SM, Shi Y, Liu H, Yuen DA (2007) Tsunami hazards along Chinese coast from potential earthquakes in South China Sea. Phys Earth Planet Inter 163(1-4):233-244. https://doi. org/10.1016/j.pepi.2007.02.012

Løvholt F, Bungum H, Harbitz CB, Glimsdal S, Lindholm CD, Pedersen G (2006) Earthquake related tsunami hazard along the western coast of Thailand. Nat Hazard 6(6):979-997. https://doi.org/10. 5194/nhess-6-979-2006

Makra K, Rovithis E, Riga E, Raptakis D, Pitilakis K (2021) Amplification features and observed damages in İzmir (Turkey) due to 2020 Samos (Aegean Sea) earthquake: identifying basin effects and design requirements. Bull Earthq Eng. https://doi.org/10.1007/s10518-021-01148-3

Manos GC (2020) The 30th of October Samos-Greece Earthquake. Issues relevant to the protection from structural damage caused by strong earthquake ground motions. Architect Eng 5(4):03-17

METU (2020) October 30, 2020 Izmir-Seferihisar Offshore (Sisam) Earthquake (Mw6.6) reconnaissance observation and findings, Metu Report No:ODTU/DMAM 2020-03.

Mimura N, Yasuhara K, Kawagoe S, Yokoki H, Kazama S (2011) Damage from the great east Japan Earthquake and Tsunami-a quick report. Mitig Adapt Strat Glob Change 16(7):803-818. https://doi. org/10.1007/s11027-011-9297-7

Onat O (2019) Experimental damage evaluation of prototype infill wall based on forced vibration test. Adv Concr Constr 8(2):77-90

Onat O, Panto B (2021) Parametric nonlinear static analysis of a RC structure with TLCW exposed to bidirectional earthquake load by using different modelling methodologies. J Build Eng. https://doi. org/10.1016/j.jobe.2021.103395

Onat O, Correia AA, Lourenço PB, Koçak A (2018) Assessment of the combined in-plane and out-ofplane behavior of brick infill walls within reinforced concrete frames under seismic loading. Earthq Eng Struct Dynam 47(14):2821-2839. https://doi.org/10.1002/eqe.3111

Pamuk E, Gönenç T, Özdağ ÖC, Akgün M (2018) 3D bedrock structure of Bornova plain and its surroundings (İzmir/western Turkey). Pure Appl Geophys 175(1):325-340. https://doi.org/10.1007/ s00024-017-1681-0

Saatcioglu M et al (2001) The August 17, 1999, Kocaeli (Turkey) earthquake damage to structures Canadian. J Civ Eng 28:715-737. https://doi.org/10.1139/101-043

Sayın E, Yön B, Calayır Y, Karaton M (2013) Failures of masonry and adobe buildings during the June

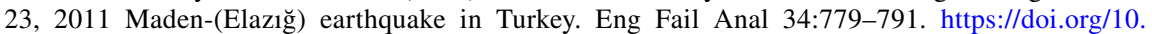
1016/j.engfailanal.2012.10.016

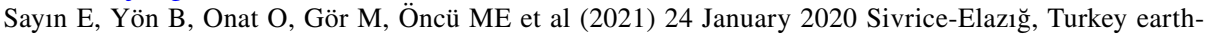
quake: geotechnical evaluation and performance of structures. Bull Earthq Eng 19(2):657-684. https://doi.org/10.1007/s10518-020-01018-4

Sayin E, Yon B, Calayir Y, Gor M (2014) Construction failures of masonry and adobe buildings during the 2011 Van earthquakes in Turkey. Struct Eng Mech 51(3):503-518

Sesetyan K, Demircioglu MB, Duman TY, Can T, Tekin S, Azak TE, Fercan ÖZ (2018) A probabilistic seismic hazard assessment for the Turkish territory_ part I: the area source model. Bull Earthq Eng 16(8):3367-3397. https://doi.org/10.1007/s10518-016-0005-6

Sezen H, Whittaker A, Elwood K, Mosalam K (2003) Performance of reinforced concrete buildings during the August 17, 1999 Kocaeli, Turkey earthquake, and seismic design and construction practise in Turkey. Eng Struct 25:103-114. https://doi.org/10.1016/j.engstruct.2004.02.005

Stepinac M, Lourenço PB, Atalić J, Kišiček T, Uroš M, Baniček M, Novak MŠ (2021) Damage classification of residential buildings in historical downtown after the ML5.5 earthquake in Zagreb, Croatia in 2020. Int J Disast Risk Reduct. https://doi.org/10.1016/j.ijdrr.2021.102140

Taskin B, Sezen A, Tugsal UM, Erken A (2013) The aftermath of 2011 Van earthquakes: evaluation of strong motion, geotechnical and structural issues. Bull Earthq Eng 11(1):285-312. https://doi.org/10. 1007/s10518-012-9356-9 
Tena-Colunga A (2021) Conditions of structural irregularity. Relationships with observed earthquake damage in Mexico City in 2017. Soil Dyn Earthq Eng 143:106630. https://doi.org/10.1016/j.soildyn.2021. 106630

TSC1968, (1968), Ministry of Construction and Settlement, Regulation on Buildings to be Built in Disaster Areas, Ankara (in Turkish)

TSC1975, (1975), Ministry of Construction and Settlement, Regulation on Buildings to be Built in Disaster Areas, Ankara (in Turkish)

TSC1998, (1998), Ministry of Construction and Settlement, Regulation on Buildings to be Built in Disaster Areas, Ankara (in Turkish)

Turkish Building Earthquake Code (2018) Ministry of Environment and Urban Planning, Ankara (in Turkish)

Turkish Earthquake Code (2007), Ministry of Public Works and Settlement, Ankara (in Turkish)

URL1: https://www.preventionweb.net/english/hyogo/gar/report/documents/GAR_Chapter_2_2009_eng. pdf

URL2: $\quad$ https://www.dailysabah.com/turkey/unsafe-buildings-worsened-impact-of-izmir-earthquake-inwestern-turkey/news

Utkucu M, Nalbant SS, Pinar A, McCloskey J, Bhloscaidh MN et al (2021) The June 12, 2017 M6.3 Karaburun-Lesvos earthquake of the northern Aegean sea: aftershock forecasting and stress transfer. Tectonophysics. https://doi.org/10.1016/j.tecto.2021.228945

Vlachakis G, Vlachaki E, Lourenço PB (2020) Learning from failure: Damage and failure of masonry structures, after the 2017 Lesvos earthquake (Greece). Eng Fail Anal 117:104803. https://doi.org/10.1016/j. engfailanal.2020.104803

Widiyanto W, Santoso PB, Hsiao SC, Imananta RT (2019) Post-event field survey of 28 September 2018 Sulawesi earthquake and tsunami. Nat Hazard 19(12):2781-2794. https://doi.org/10.5194/ nhess-19-2781-2019

Yön B (2021) Identification of failure mechanisms in existing unreinforced masonry buildings in rural areas after April 4, 2019 earthquake in Turkey. J Build Eng 43:102586. https://doi.org/10.1016/j.jobe.2021. 102586

Yön B, Sayın E, Köksal TS (2013) Seismic response of buildings during the May 19, 2011 Simav Turkey earthquake. Earthq Struct 5(3):343-357. https://doi.org/10.12989/eas.2013.5.3.343

Yön B, Sayın E, Calayır Y, Ulucan ZC, Karataş M et al (2015) Lessons learned from recent destructive Van Turkey earthquakes. Earthq Struct 9(2):431-453

Yön B, Sayın E, Onat O (2017) Earthquakes and structural damages. In: Zouaghi T (ed) Earthquakes-tectonics, hazard and risk mitigation. InTech, Rijeka, pp 319-339. https://doi.org/10.5772/65425

Yön B, Onat O, Öncü ME (2019) Earthquake damage to nonstructural elements of reinforced concrete buildings during 2011 Van seismic sequence. J Perform Constr Facil 33(6):04019075. https://doi.org/ 10.1061/(ASCE)CF.1943-5509.0001341

Yön B, Onat O, Öncü ME, Karaşin A, (2020) Failures of masonry dwelling triggered by East Anatolian Fault earthquakes in Turkey. Soil Dyn Earthq Eng 133:106126. https://doi.org/10.1016/j.soildyn.2020. 106126

Yurdakul Ö, Duran B, Tunaboyu O, Avşar Ö (2021) Field reconnaissance on seismic performance of RC buildings after the January 24, 2020 Elazı ̆-Sivrice earthquake. Nat Hazards 105(1):859-887. https:// doi.org/10.1007/s11069-020-04340-X

Publisher's Note Springer Nature remains neutral with regard to jurisdictional claims in published maps and institutional affiliations. 